\title{
تقييم الأداء الوظيفي والجمالي للمفروشات (الفوط) المطرزة بأسلوب التطريز بشرائط الساتان
}

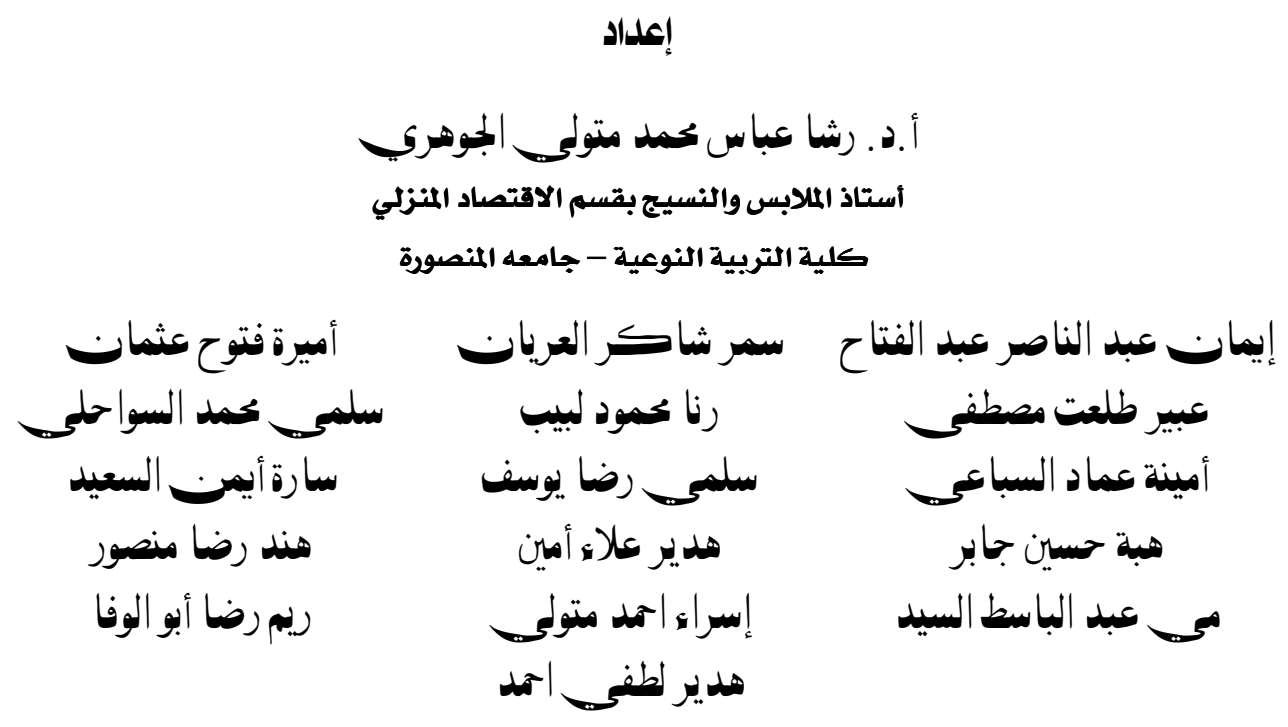

مجلة بحوث التربية النوعية ـ جامعة المنصورة

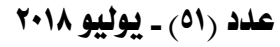


مجلة بحوث التربية النوعية - علد اه - بوليو r.11

\section{تقييم الأداء الوظيفي والبمالي للامفروشات (الفوط) الاطلرزة}

\section{بأسلوب التطريز بشرائط الساتان}

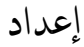

$$
\begin{aligned}
& \text { أ.د . رشا عباسمحمد متوليالجوهريــ }
\end{aligned}
$$

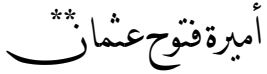

$$
\begin{aligned}
& \text { سلمي محمد السواحليمت* } \\
& \text { سارة أُم:السعبد** }
\end{aligned}
$$

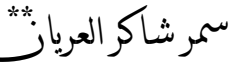

$$
\begin{aligned}
& \text { إيمازغبد الناصر عبد الفتّح } \\
& \text { رنا محمود لبيب } \\
& \text { عبر طلعت مصطفح * * } \\
& \text { سلميرضا يوسفت } \\
& \text { أمينة عماد السباعَ* } \\
& \text { هند رضا منصور } \\
& \text { هدير علاء أمب. }
\end{aligned}
$$

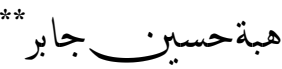

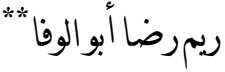

$$
\begin{aligned}
& \text { إسراء احمد مهوليم** } \\
& \text { مي عبد الباسط السيد"* } \\
& \text { هدير لطغ احمد"* }
\end{aligned}
$$

ال|لغص

يهدف البحث الى تقيم الاداء الوظيفى والجمالى للمفروشات (الفوطهالمطرزة باسلوب

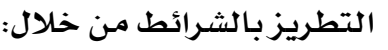

الاستفادة من القيم الجمالية لفن التطريز بشرائط الستان لاثراء المفروشات المنزلية

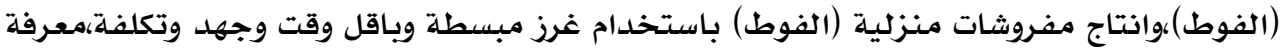

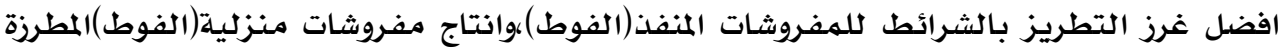

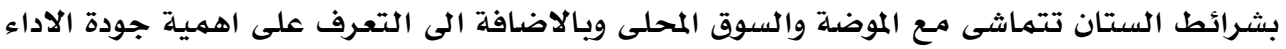

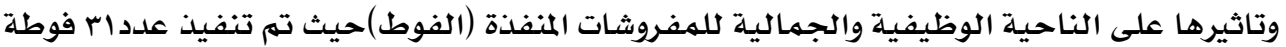
واعداد استمارة تقيم اشتملت على ثلاث محاور وهى (الناحية الوظيفية،الناحية الجمالية ،ناحية 


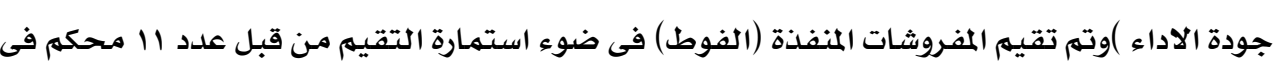

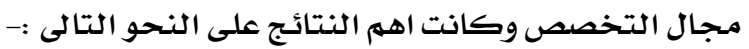

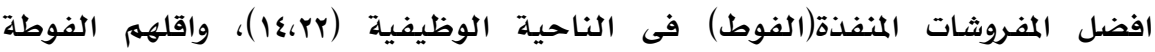

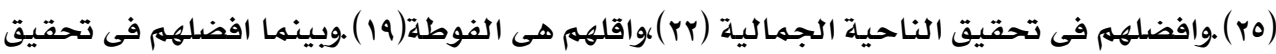

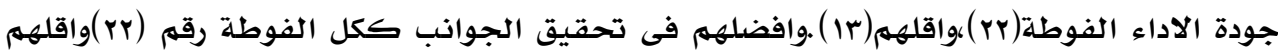
الفوطة رقم(1) (1).

الاقدهمة :

التطريز فن من الفنون الزخرفية الجميلة التي استعان بها الإنسان لتزيين ملابسـه وأدواته

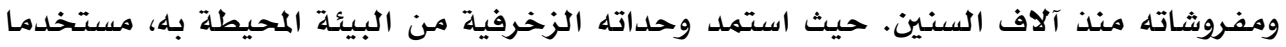

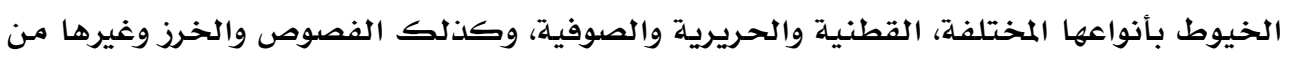

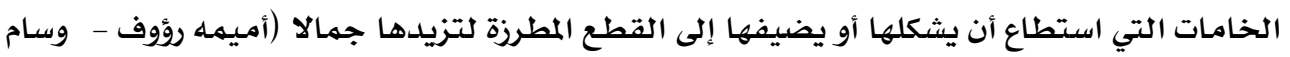
مصطفى , r.10)

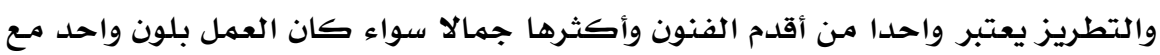

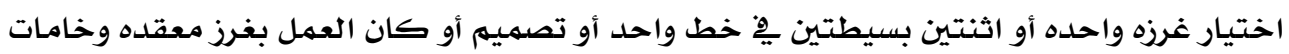

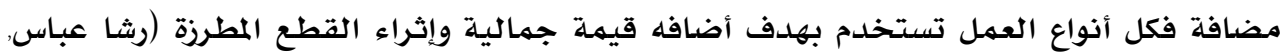
. $(r+1$.

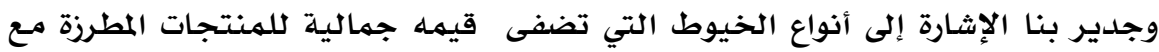

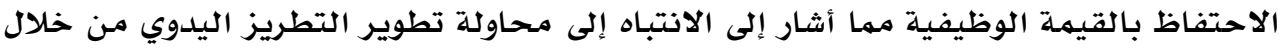

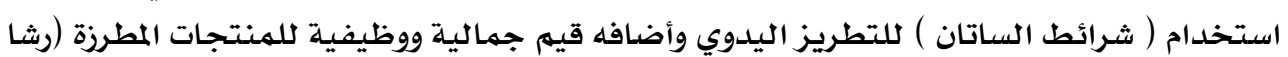

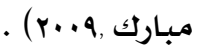

ومن الدراسـات التي اهتمت بالتطريز بالشرائط دراسة " رشـا مبارك, 9 ...ب" وتهدف إلي دراسـة

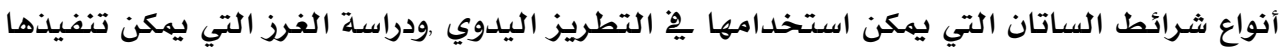

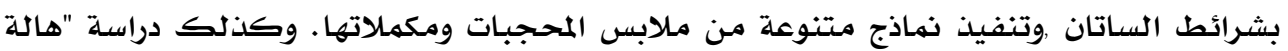

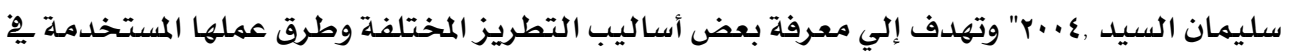

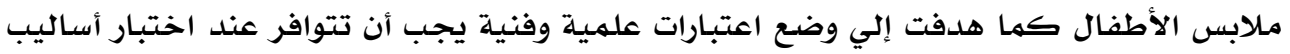

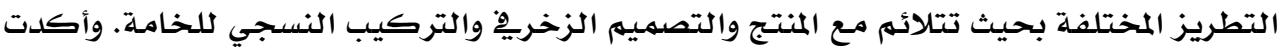

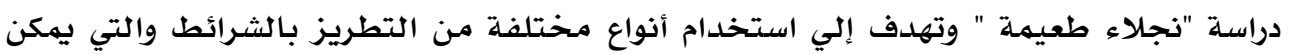

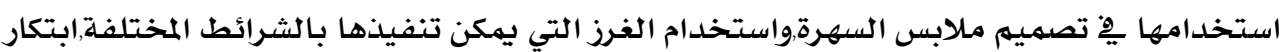

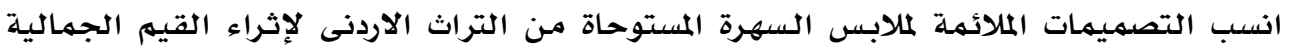

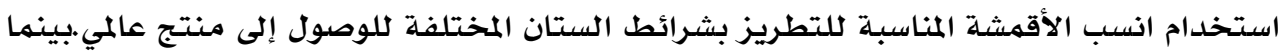

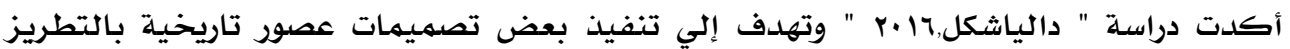

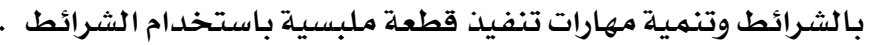


وتعد المفروشات من الضروريات الكلازمة لكل منزل لما لها من أهميه جمالية ووظيفية ولا

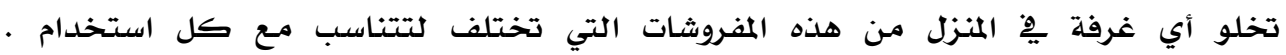

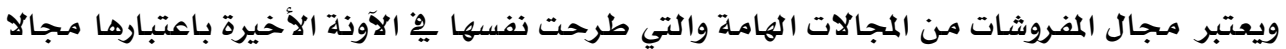

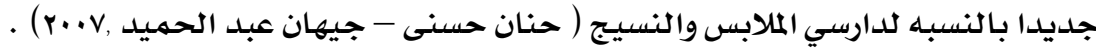

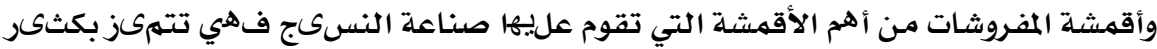

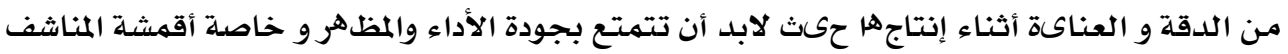

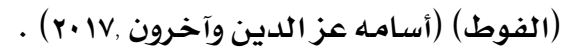

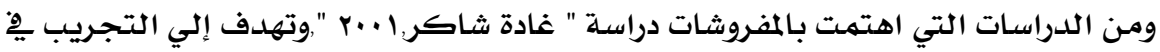

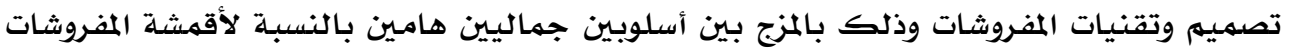

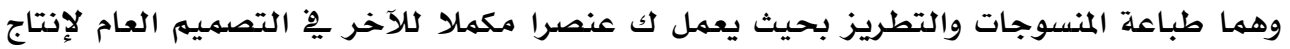

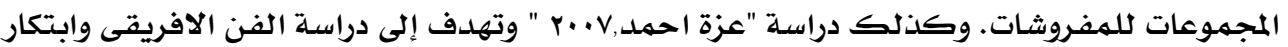

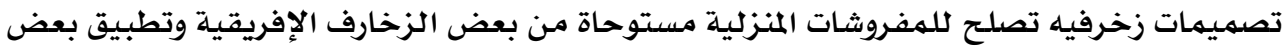

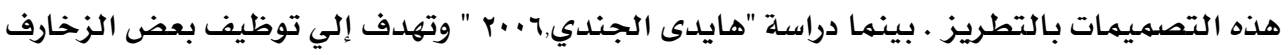

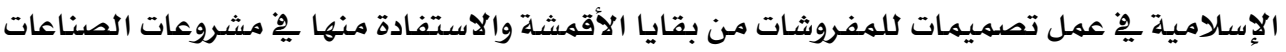
الصغيرة . الإسامئ.

ونظرا لأهمية المفروشات الوظيفية والجمالية والتي تعتبر من الضروريات اللازمة لكل منزل

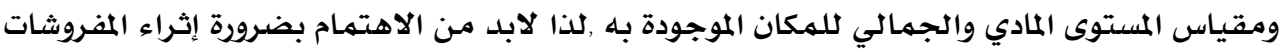

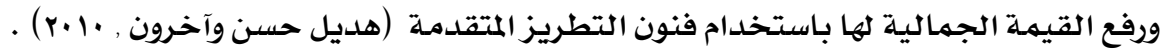
ومما سبق يمكن تحديل مشكله البحث يٍ التساؤل الرئيس كالآتي:• ما إمكانية إثراء المفروشات (الفوط) ورفع القيمة الجمالية لها باستخدام فن التطريز

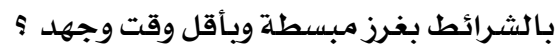

ومن التساؤل الرئيس يتفرع عدة تساؤلات فرعية وهي : 1- ما أفضل غرز التطريز بالشرائط للمفروشات (الفوط) ؟

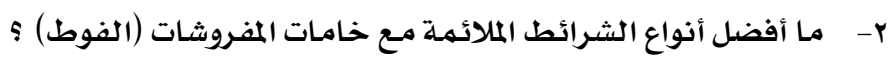

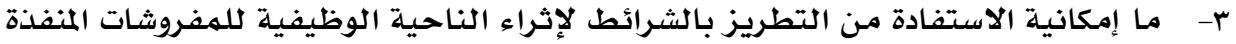

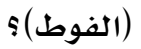
ع-ما إمكانية الاستفادة من التطريز بالشرائط لإثراء الناحية الجمالية للمفروشات المنفذة

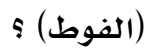
ه- جودة الأداء (التنفيذ) تؤدي إلي إثراء المفروشات المطرزة (الفوط) بالشرائط . 
استهدف هذا البحث تقييم الأداء الوظيفي والجمالي للمفروشات (الفوط) المطرزة بأسلوب

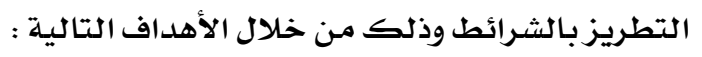

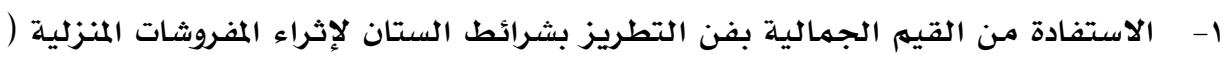

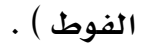

r- إنتاج مفروشات منزلية (الفوط) باستخدام فن التطريز بالشرائط بغرز مبسطة وبأقل وقت

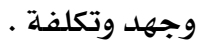

$$
\text { r- معرفة أفضل غرز التطريز بالشرائط للمفروشات (الفوط) . }
$$

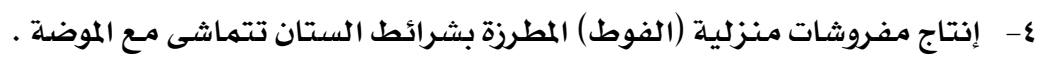

ه- إنتاج مفروشات منزلية (الفوط) المطرزة بشرائط الستان تتماشى مـع السوق المحلى .

ج- التعرف على أهمية جودة الأداء وتأثيرها على الناحية الجمالية والوظيفية للمفروشات

$$
\text { (الفوط). (التعرف). }
$$

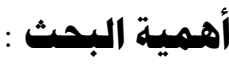

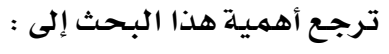

1- القاء الضوء على فن التطريز بشرائط الستان .

r- تقييم الاداء الوظيفى للمفروشات المنزلية (الفوط) المطرزة بشرائط الستان تتماشى مـع

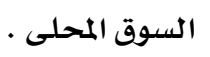

r- يسهم هذا البحث فى اضافة قيمة جمالية للمفروشات (الفوط) المطرزة بشرائط الستان .

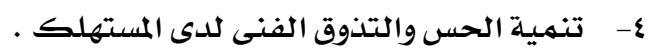

هدود البمث :

\section{حلدود نوعيه:}

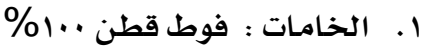

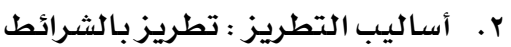

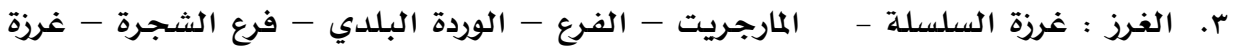

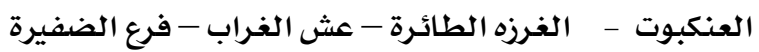

حدود زمانية:

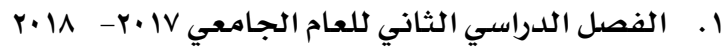




\section{هنهج البحث : \\ المنهج الوصفى و المنهج التجريبى

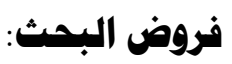

ا- توجد فروق ذات دلالة إحصائية بين المفروشات (الفوط) المطرزة بأسلوب التطريز بالشرائط

هِِ تحقيق الناحية الوظيفية وفقا لآراء المحكمـينت

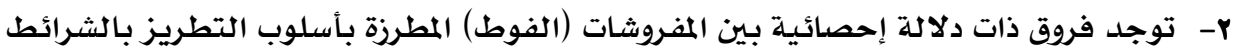

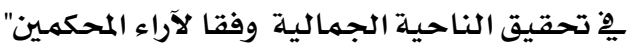

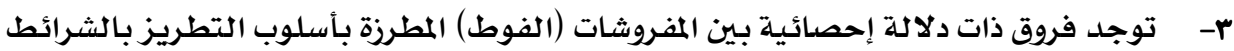

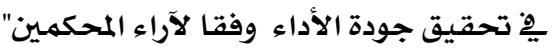

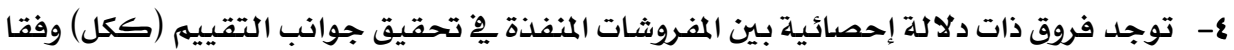

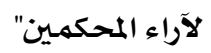

هـ توجد فروق ذات دلادلة إحصائية بين محاور تقييم المفروشات المنفذة وفقا لآراء المحكمـين "

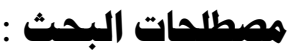

المفروشات:-

- هي جميع الفرث المستعمل لإحداث تغيير علي الشكل الخارجي للمنزل وتتعدد أنواعها فمنها

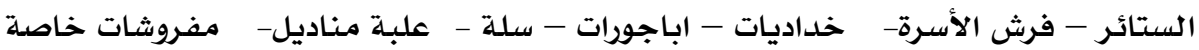

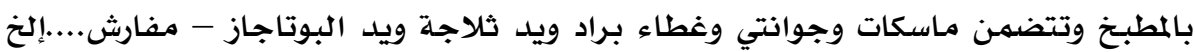
(سامية الطوبشي, 1999) .

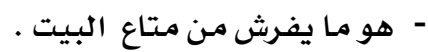

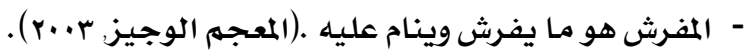

المفروشات المنزلية

- يقصد بها المفروشات التي تستعمل بالمنزل مثل ملاءات الأسرة ومفارث السفرة والفوط (مليهل

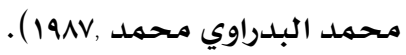

التطريز

- التطريز اسم اعجمي مشتق من الكلمة الفارسية "طرازين" ،وهي ترادف الكلمة الانجليزية Embroidery

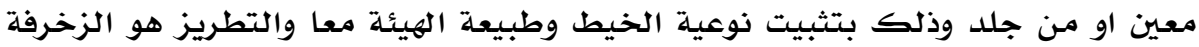

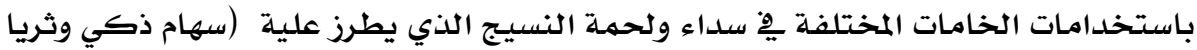

(1999, نصر ونفيسة عبد الرحمن الخات 
- هو نوع اخر من التطريز ويستخدم مِّ تنفيذه نفس الخامات من خيط وقماش مضاف اليها

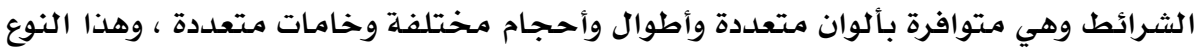

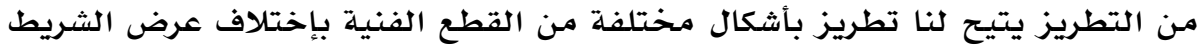

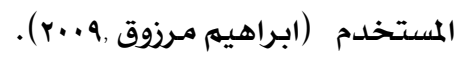

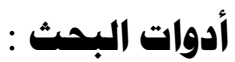
جدول (1) يوضح ادوات البحث الأدوات :

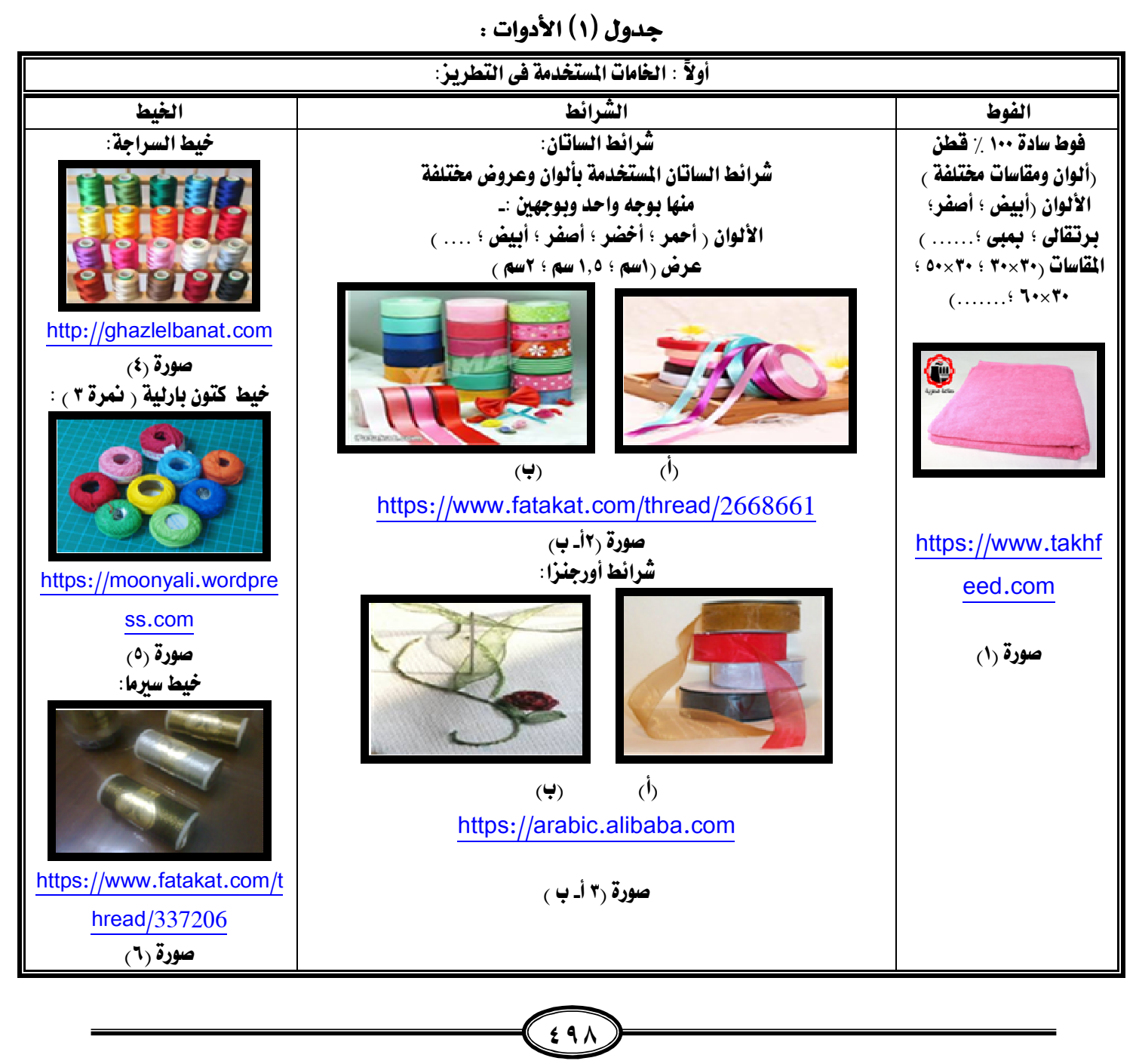




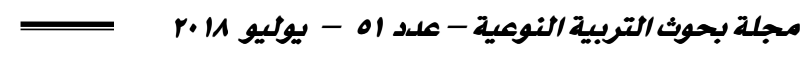

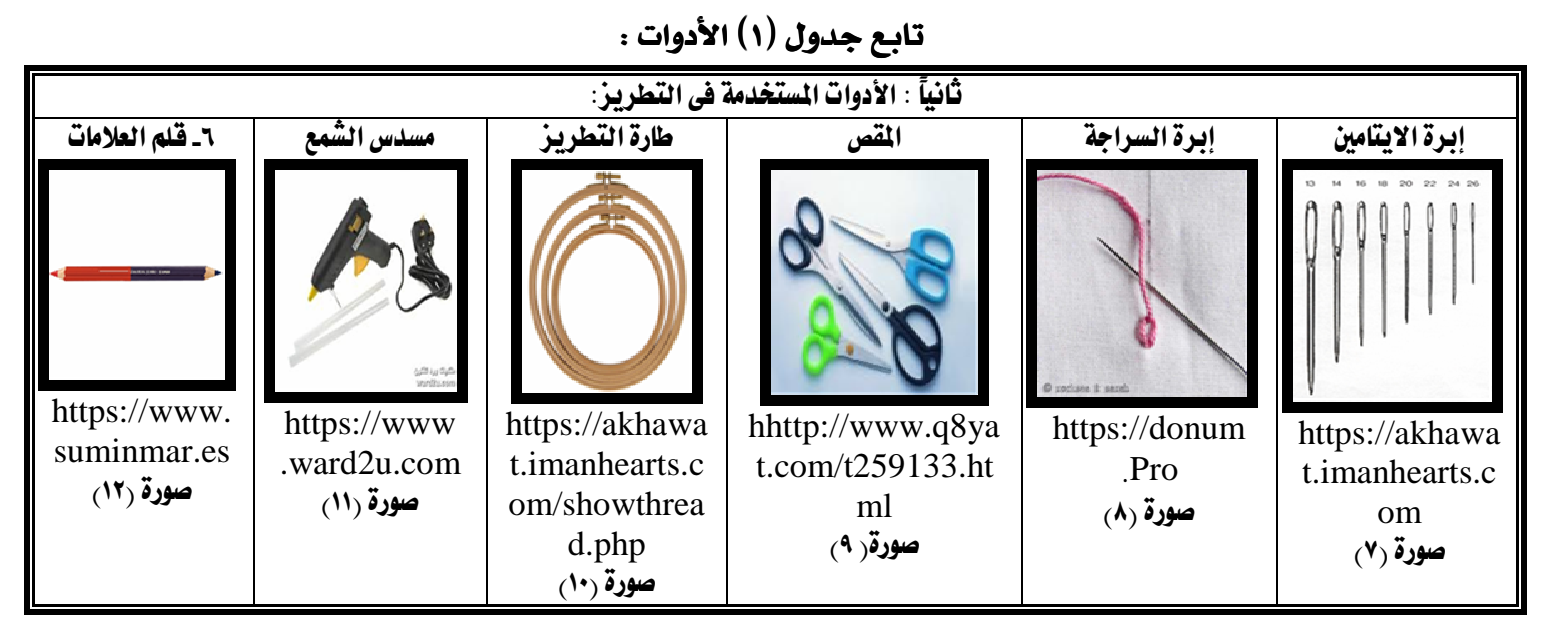

$$
\text { تابع جدول (1) الأدوات : }
$$

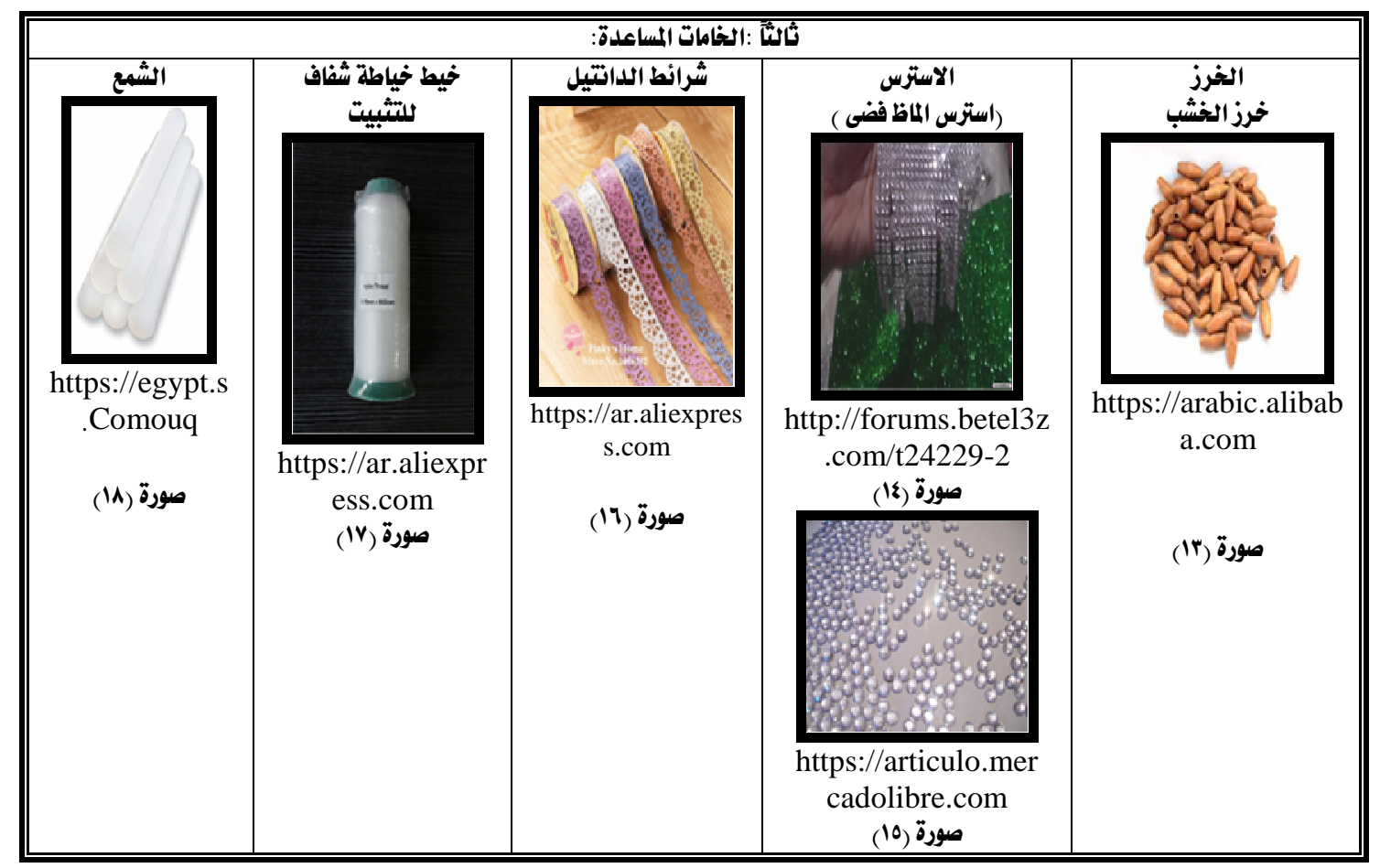




\section{= = ت بييه الأداء الوظيفي والجمالي للمفروشات (الفوط) المطرزة باسلوب التطريزبشرائط الساتان \\ رابعا استمهارة استبيان لتقييم الفمروشات المنفذة(الفوطة)}

اشتملت استمارة التقييم علي ثلاث محاور وهم: المحور الاول الناحية الوظيفية , المحور

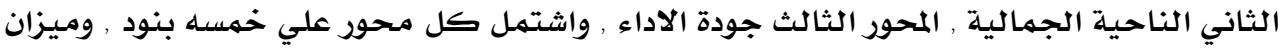

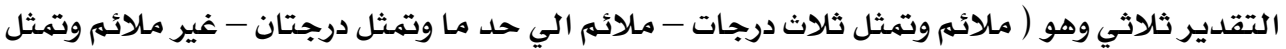

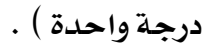

ا. الاطلاع على الدراسات المرتبطه بمحاور البحث المتمثلة ِِّ (التطريزبشرائط الستان -

(المفروشات)

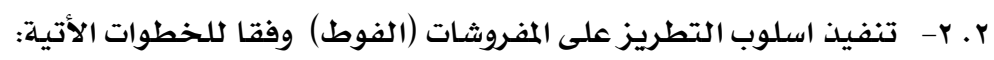

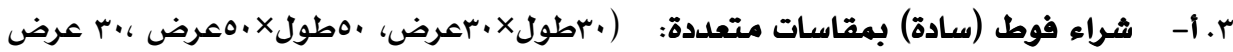

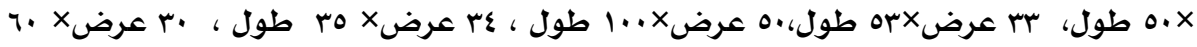

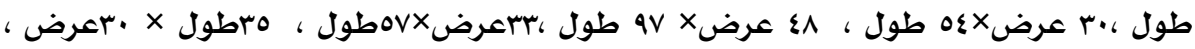

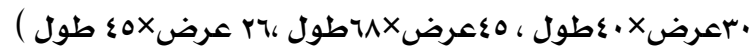

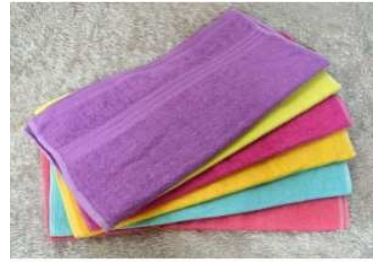

https://www.kanbkam.com/eg/ar/alkhaligia-group-akfws1-plain-towels-set$\underline{6-p c s-28021273}$

صورة)(10)

ب - تحديد التصميم المستخدم وتوزيعه.

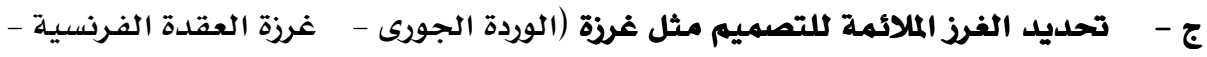
غرزة السلسلة - غرزة الشريط - غرزة الوردة البلدى - غرزة الفرع - غرزة السـراجة المزدوجـة - غرزة الحشو- غرزة التثبيت - غرزة زهرة الربيع غرزة الوردة الفستقة

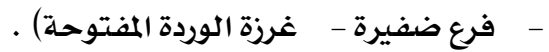

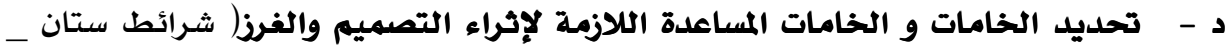

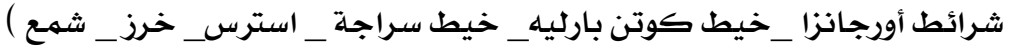

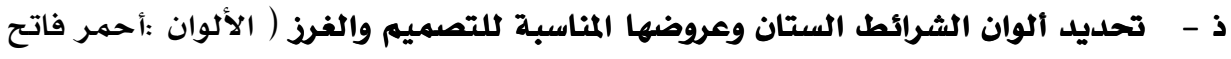
،أبيض ، أخضر فاتح ، أخضر غامق ، أزرق ، أحمر غامق ، أصفر، برتقالى ، نحاسى ، بنفسجى

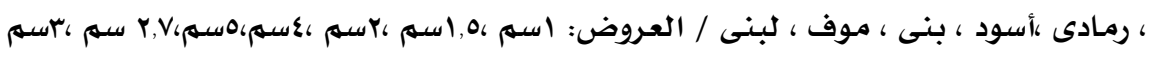
، مسهم, Tسهم) 


\section{ر- طباعه التصميم المستخدم بواسطة كريون القماش علي الفوطة.$$
\text { ز- تنفيذ غرز التطريز بالشرائط على الفوط وهى على النحو التالي : }
$$

الغرز المستخدمـة ِِّ تطريز المفروشات (الفوط) بإستخدام شرائط الستان وطريقة العمل كما هو موضتح بالصور: - - - مرزة الشريط
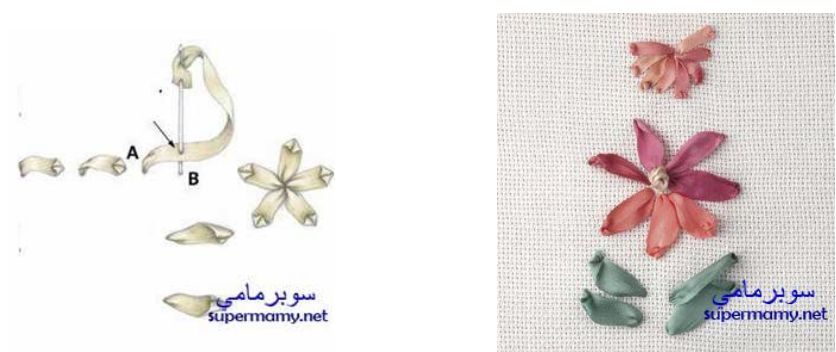

http://www.lakii.com/vb/a-17/a-651299/index2.html

صورة (1)

$$
\text { ب- غرزة زهره الربيع الكسوله : }
$$
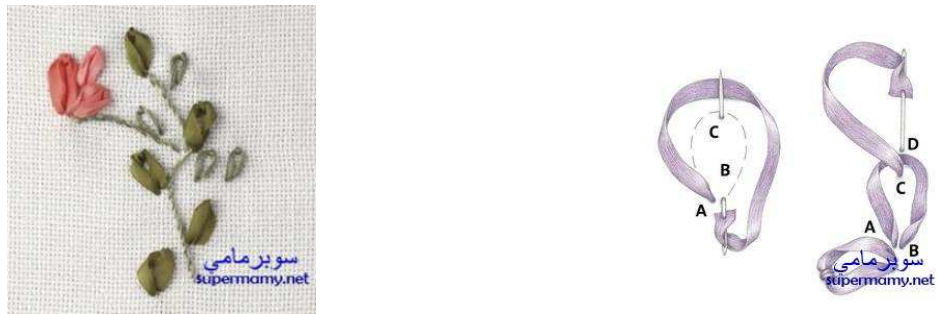

http://www.lakii.com/vb/a-17/a-651299/index2.html

صورة (Iv)

$$
\text { r_ _ غرزة العقده الفرنسيه لتطريز الشريط (الشرائط): }
$$
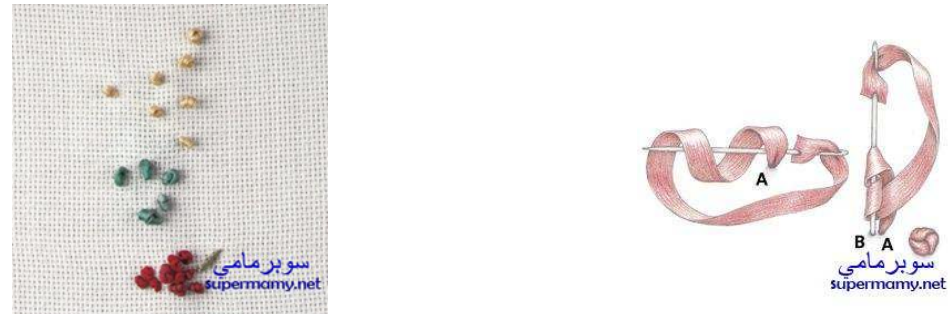

http://www.lakii.com/vb/a-17/a-651299/index2.html

صورة(1) 


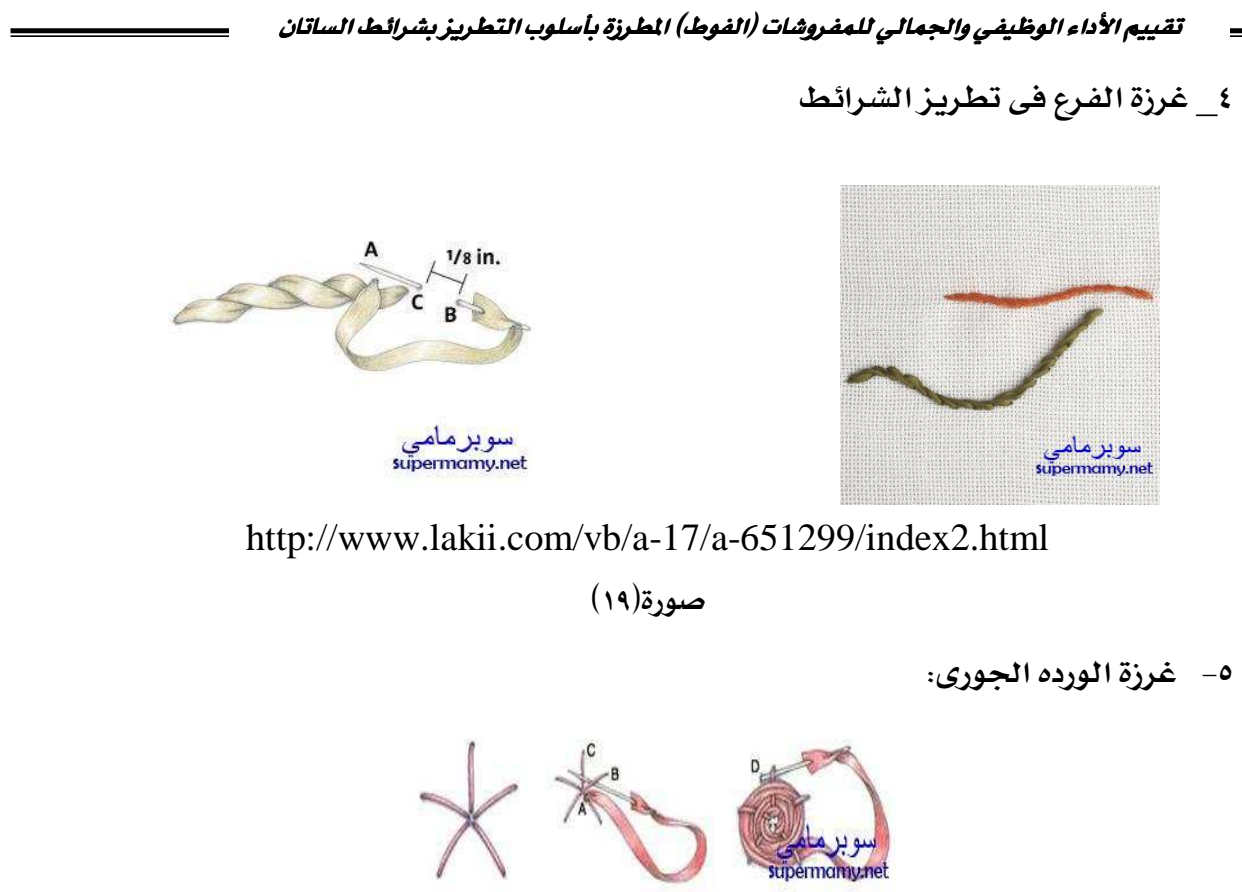

http://www.lakii.com/vb/a-17/a-651299/index2.html

$$
\text { صورة) (r) }
$$
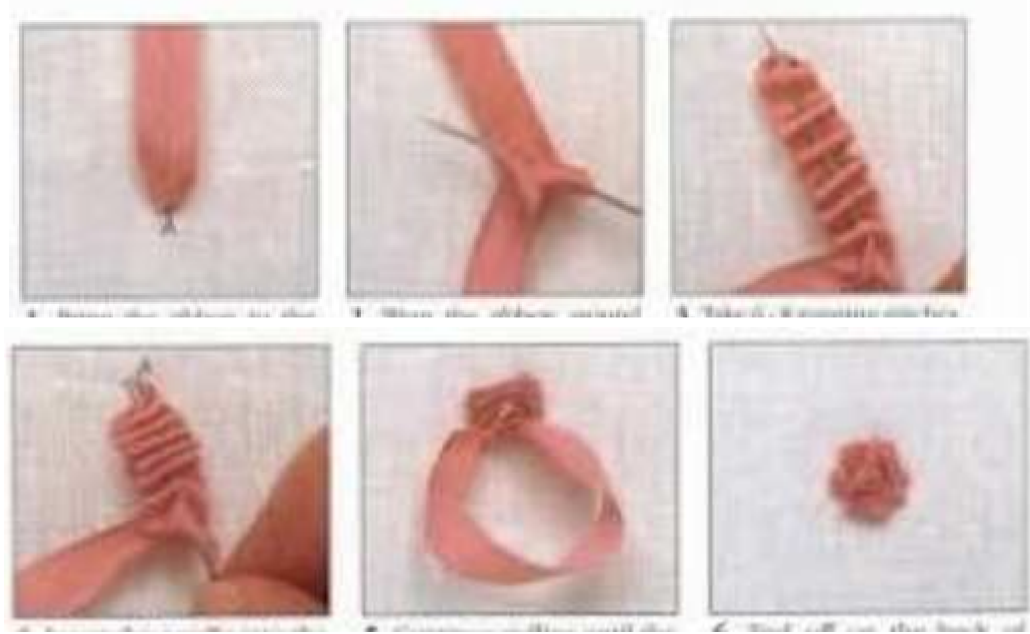

/https://dzh.univanet.com/page/834

صورة(r) 


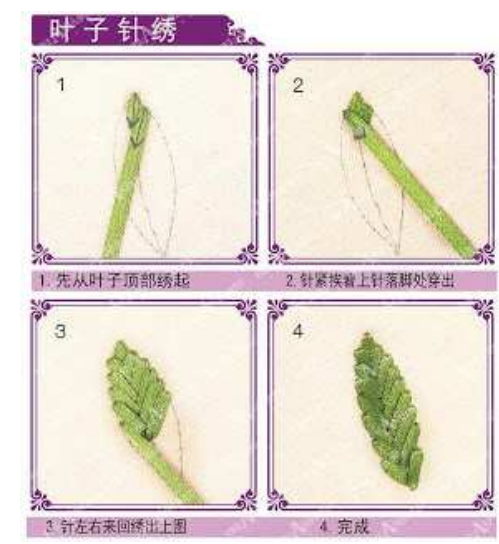

http://simsimdiary.blogspot.com.eg/2013/03/blog-post_7594.html

صورة(rr)

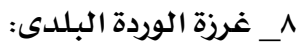
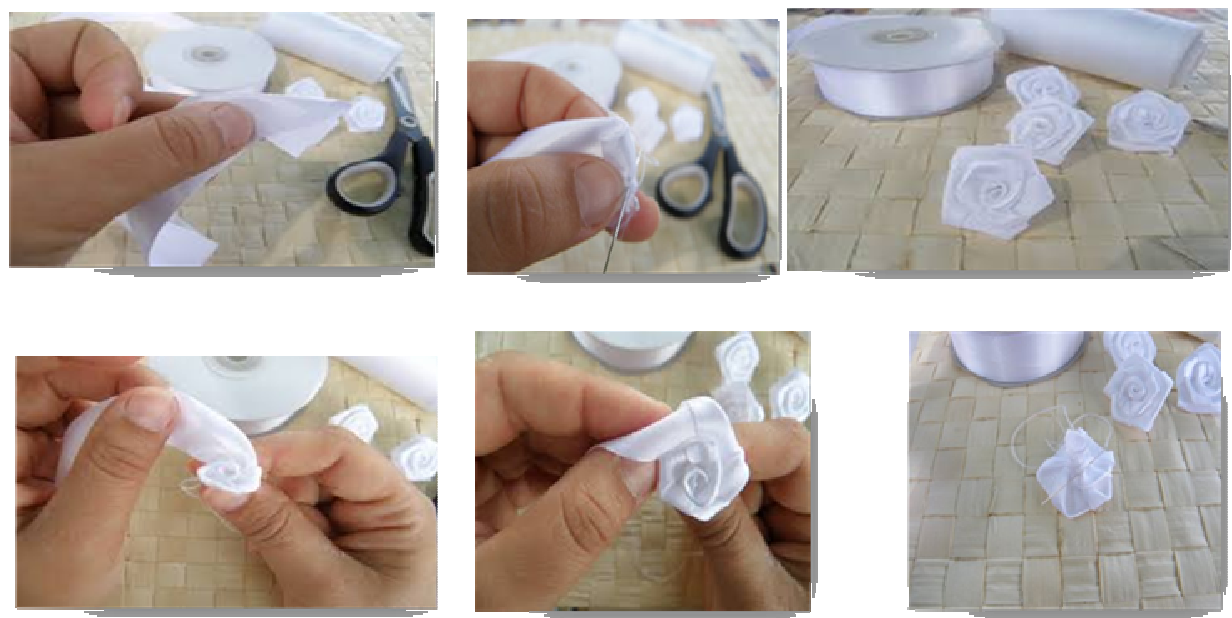

/https://www.hawaaworld.com/ \%8

صورة(rr) 


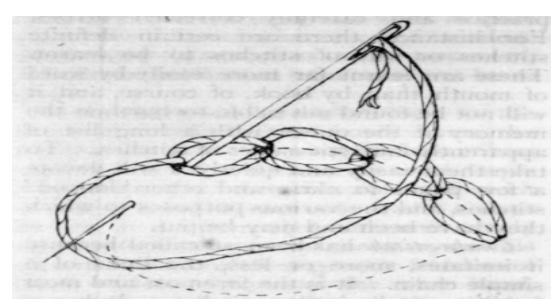

http://sidamslema.forumegypt.net/t2212-topic صورة(r乏)

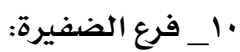

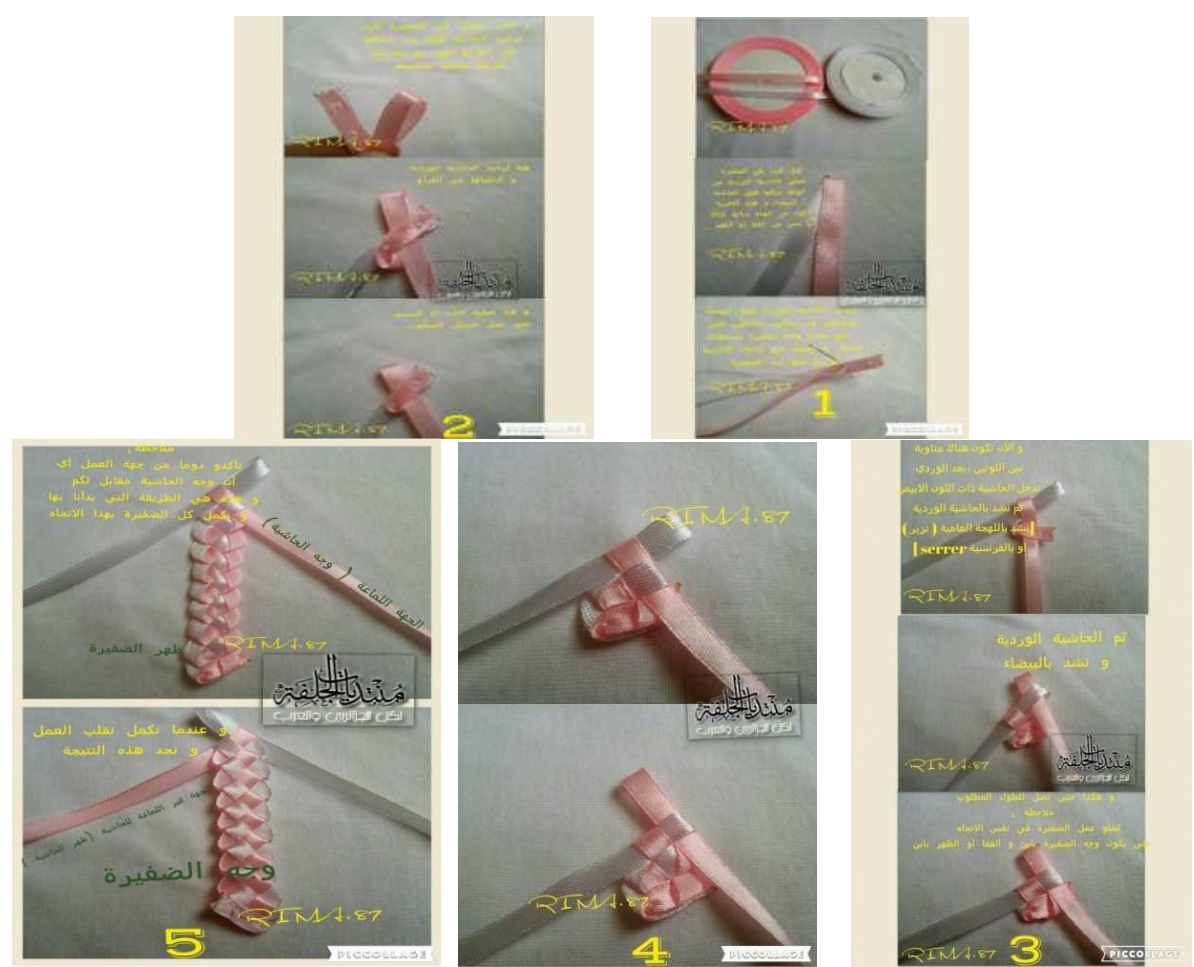

http://www.djelfa.info/vb/showthread.php?t=2016653

صورة)(ro) 


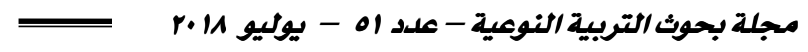

ع _وتم تنفيذ عدد اب فوطة وتوصيفها كما هو موضح بجدول (r) :

جدول (r) لتوصيف اب فوطة تم تنفذها

\begin{tabular}{|c|c|c|}
\hline التوصيف & التصميم قبل الفسيل & 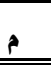 \\
\hline 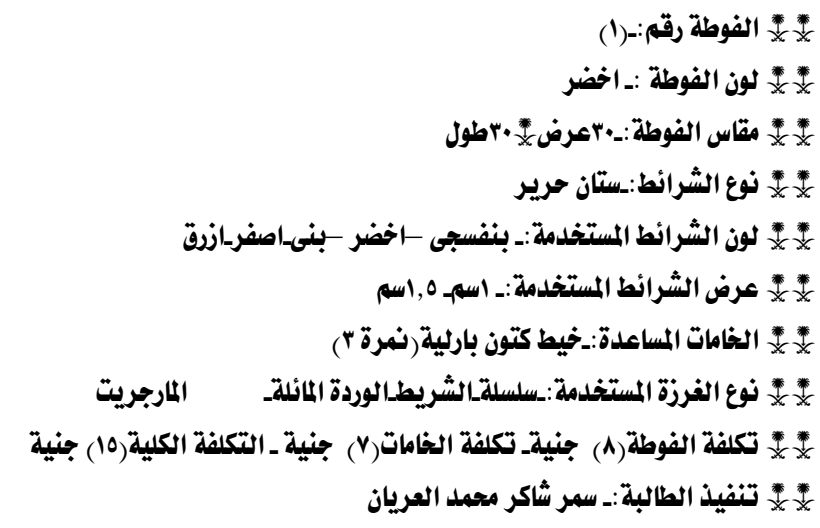 & & -1 \\
\hline 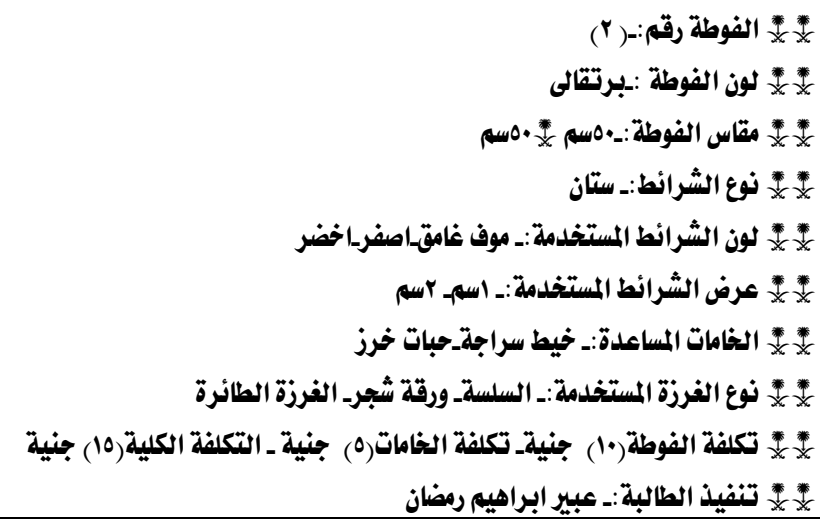 & 6 & $-r$ \\
\hline 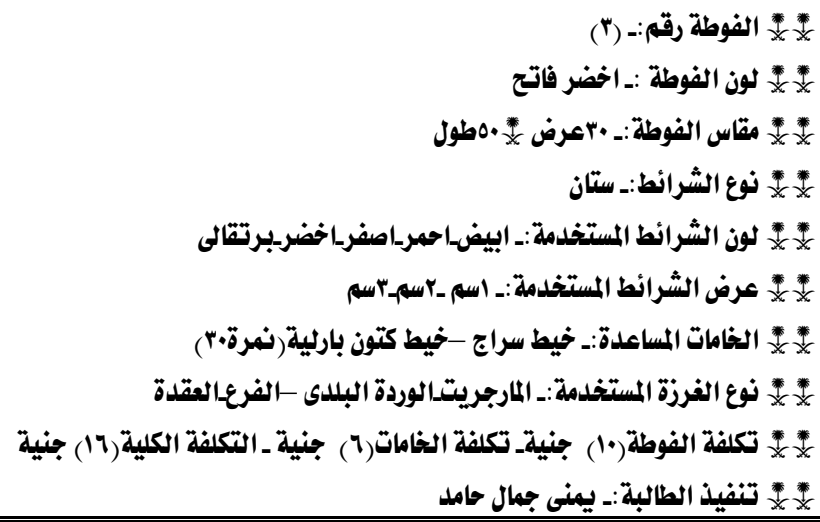 & $20 x-4$ & r \\
\hline
\end{tabular}


تقييم الأداء الوظيفي والجمالمي للمفروثات (الفوط) المطرزة باسلوب التطريزبشرائط الساتان

تابع جدول (r) لتوصيف اس فوطة تم تنفذها

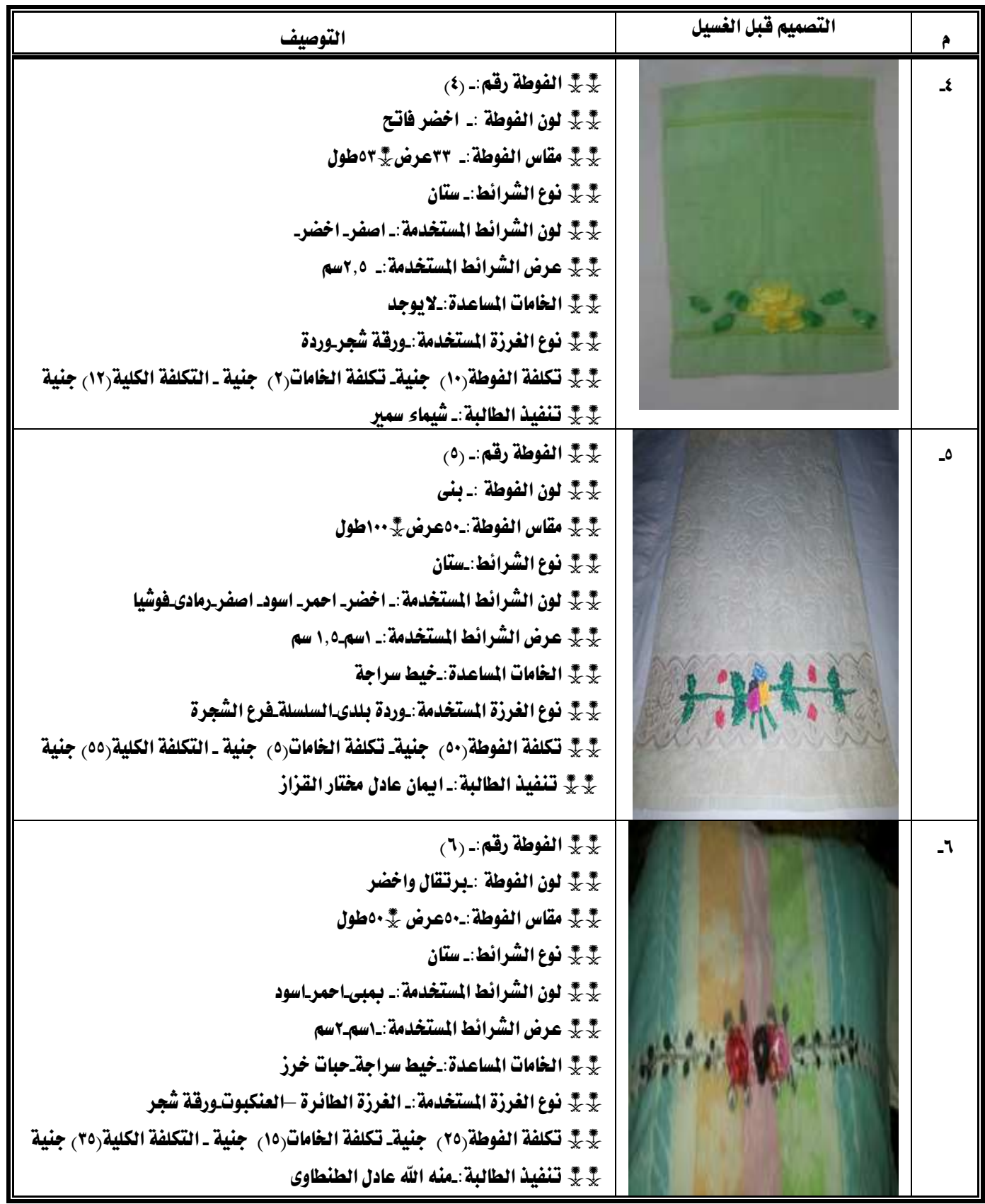




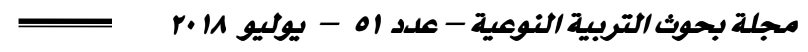

تابع جدول (r) لتوصيف اب فوطة تم تنفذها

\begin{tabular}{|c|c|c|}
\hline 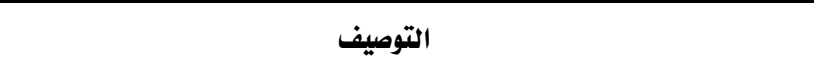 & التصميم قبل الفسيل & ค \\
\hline 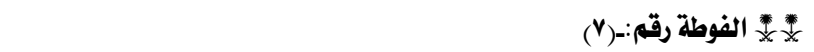 & & $-Y$ \\
\hline 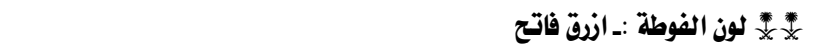 & & \\
\hline |ج & & \\
\hline 艾 نوع الشرائط:ستان & & \\
\hline 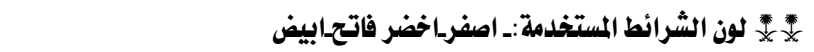 & & \\
\hline 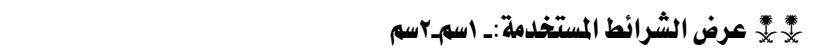 & & \\
\hline 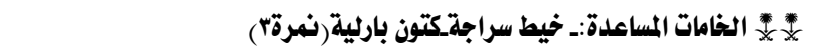 & & \\
\hline ×* * نوع الفرزة المستخدمة:_الوردة البلدى_العنكبوت_الوردة الفستقة_غرزة الفرع & & \\
\hline 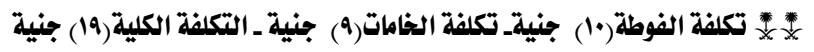 & & \\
\hline * * * تنفيذ الطالبة:_عبير طلعت مصطفى & & \\
\hline (^) & & $-\Lambda$ \\
\hline | * * لون الفوطة :ـ بنى فاتع & & \\
\hline 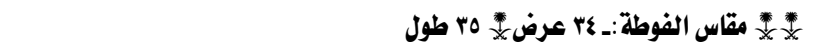 & & \\
\hline | & & \\
\hline 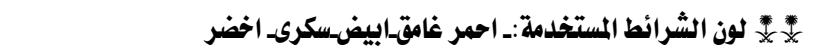 & & \\
\hline 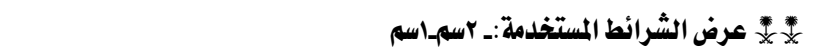 & & \\
\hline * * الخامات المساعدة:. خيط سراجة_خيط كتون باريلية (نهرة ץ) & & \\
\hline 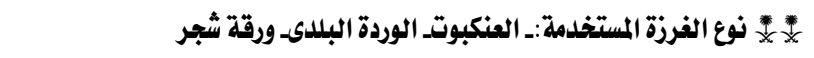 & & \\
\hline 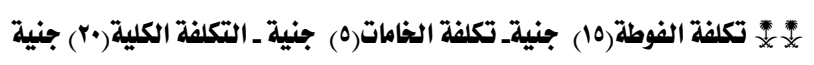 & & \\
\hline 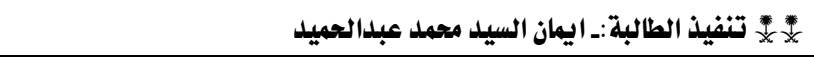 & & \\
\hline 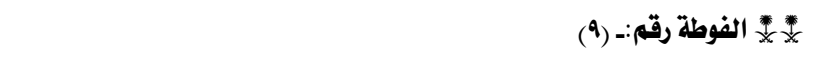 & & -9 \\
\hline 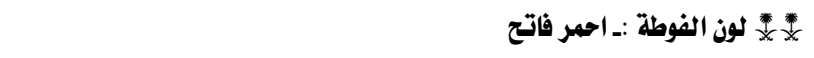 & & \\
\hline 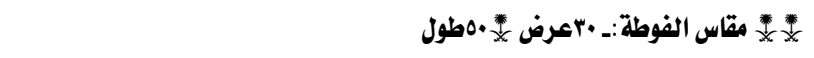 & & \\
\hline 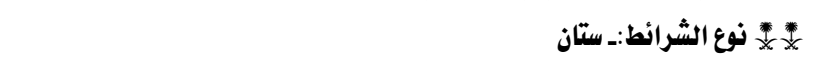 & & \\
\hline 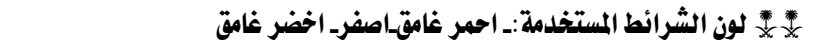 & & \\
\hline 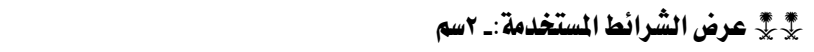 & & \\
\hline 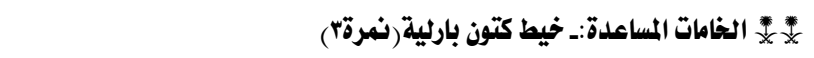 & & \\
\hline 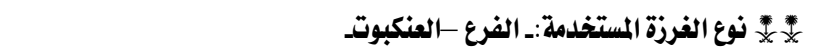 & sot & \\
\hline \& \& تكلفة الفوطة(•1) جنية_ تكلفة الخامات(ه) جنية ـ التكلفة الكلية(10) جنية & & \\
\hline 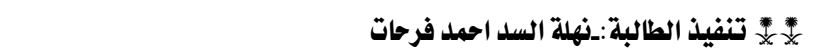 & & \\
\hline
\end{tabular}




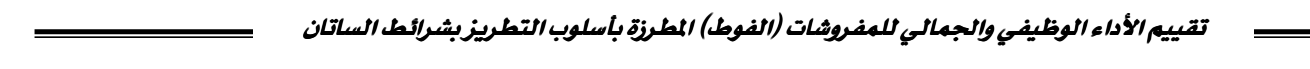
تابع جدول (ץ) لتوصيف اب فوطة تم تنفذها

\begin{tabular}{|c|c|c|}
\hline التوصيف & التصميم قبل الفسيل & \\
\hline 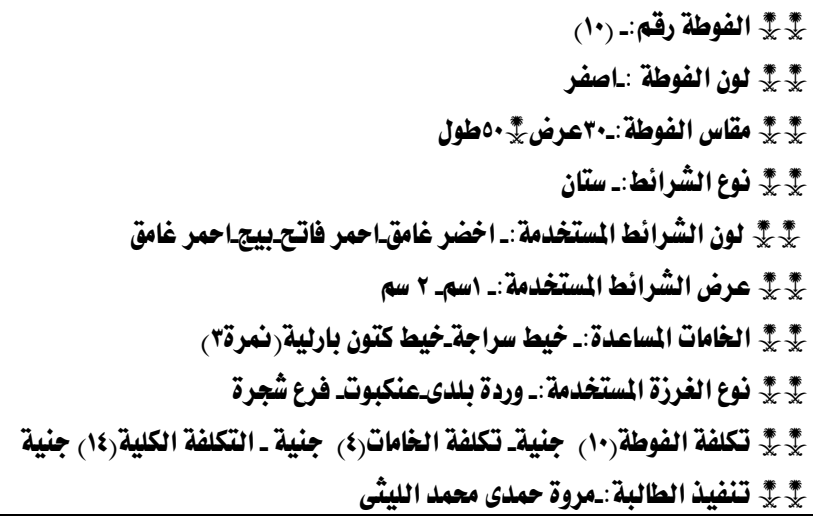 & & -1. \\
\hline 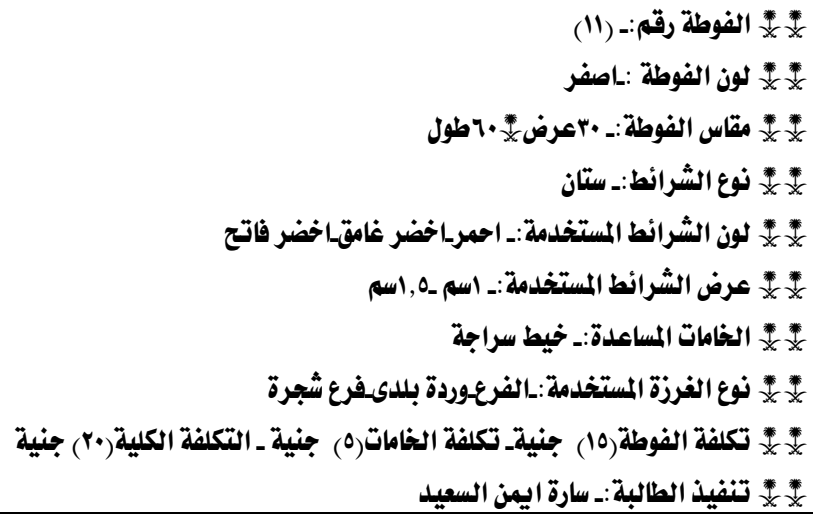 & & -11 \\
\hline 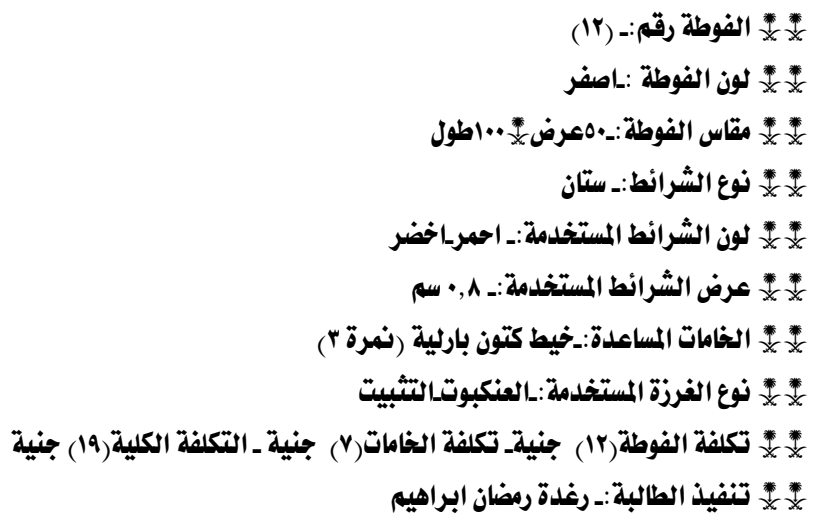 & $\theta-\infty$ & - \\
\hline
\end{tabular}




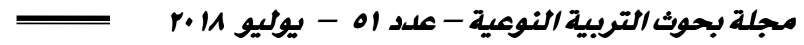

تابع جدول (r) ) لتوصيف اب فوطة تم تنفذها

\begin{tabular}{|c|c|c|}
\hline التوصيف & التصميم قبل الفسيل & A \\
\hline 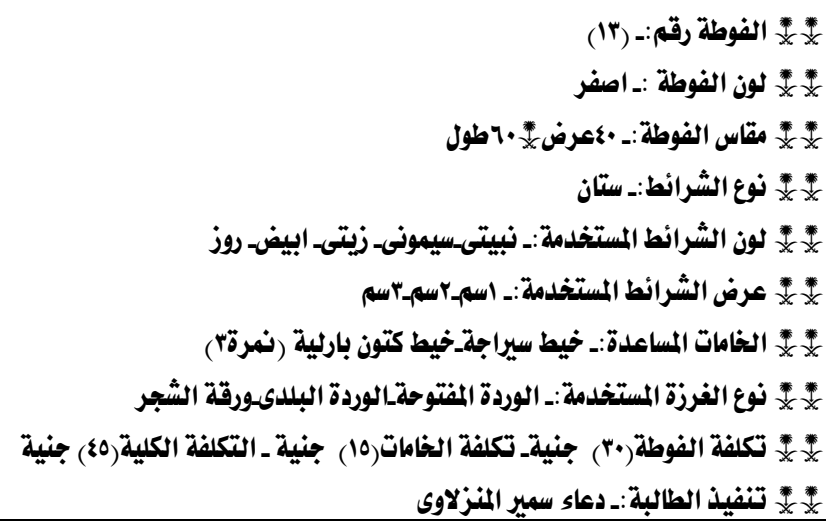 & & rit \\
\hline 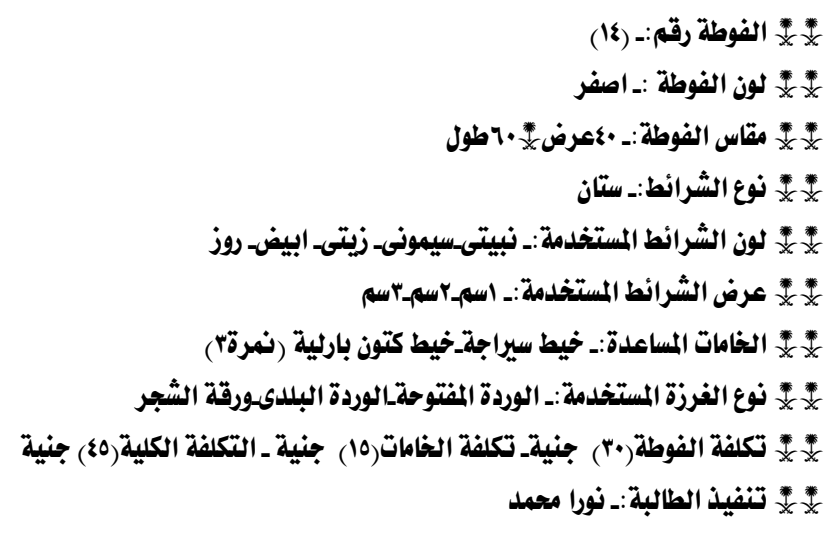 & & |k \\
\hline 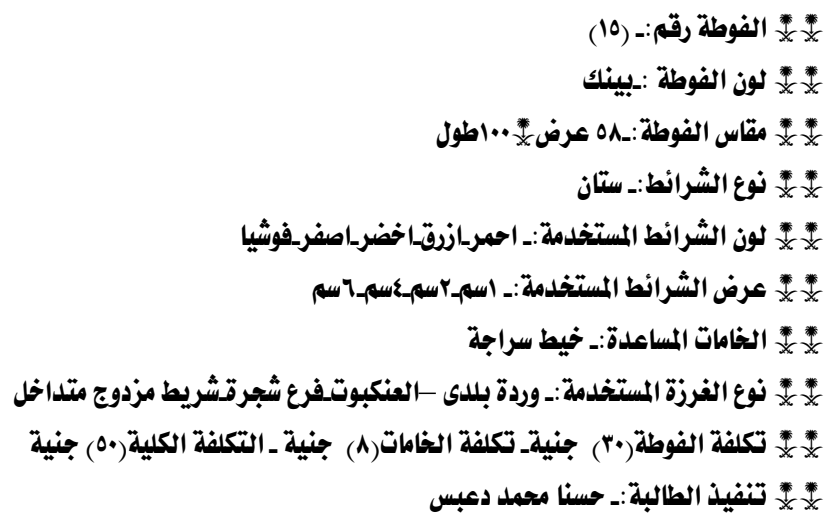 & & -10 \\
\hline
\end{tabular}


تقييم الأداء الوظيفي والجمالمي للمفروثات (الفوط) المطرزة باسلوب التطريزبشرائط الساتان

تابع جدول (r) لتوصيف اس فوطة تم تنفذها

\begin{tabular}{|c|c|c|}
\hline التوصيف & التصميم قبل الفسيل & $\hat{r}$ \\
\hline 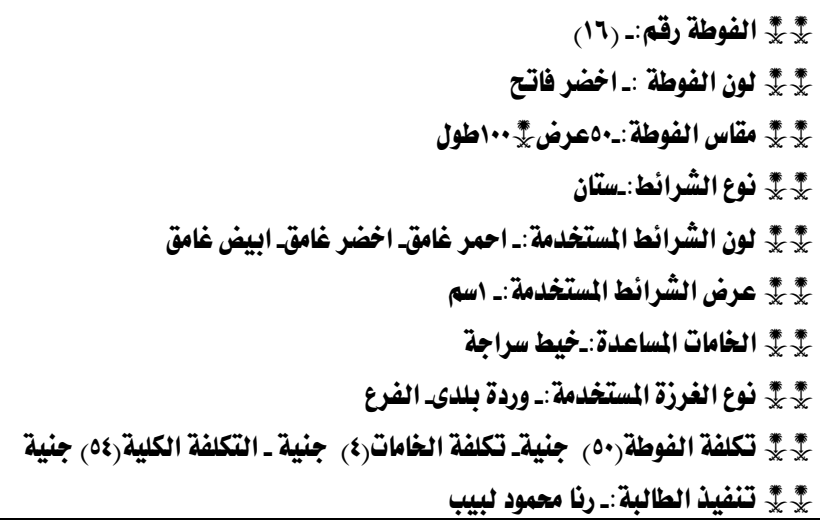 & & -17 \\
\hline 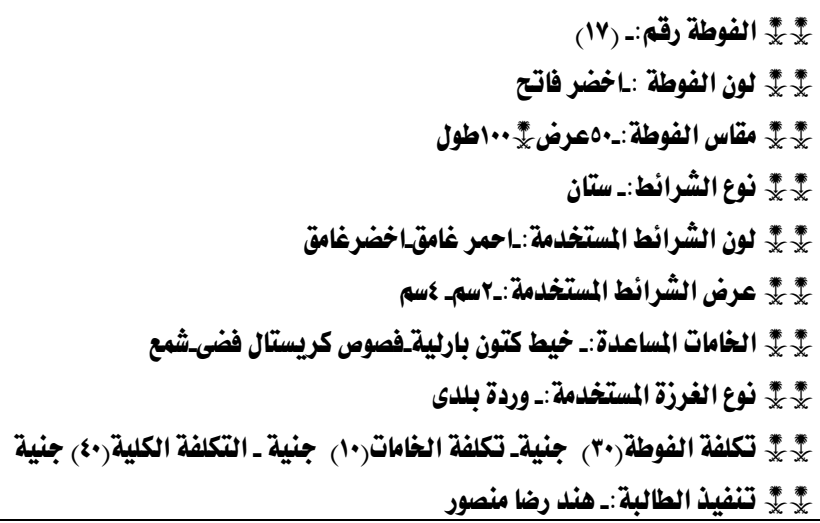 & & $-I V$ \\
\hline 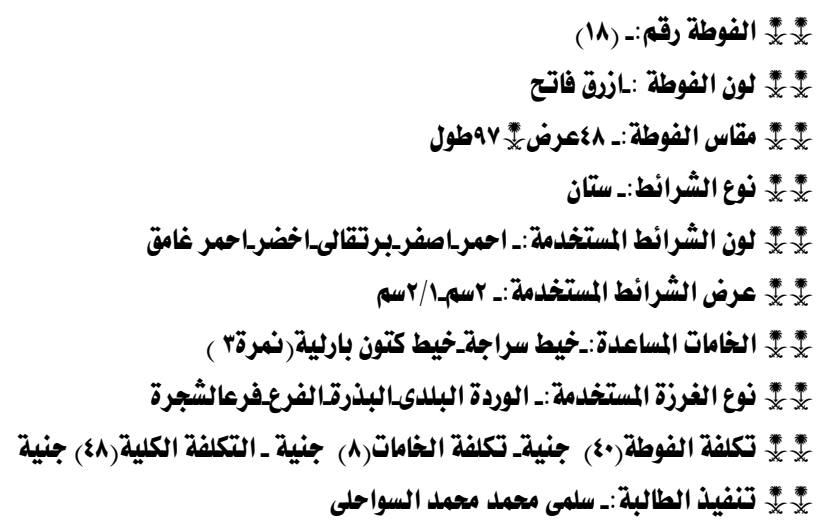 & & -11 \\
\hline
\end{tabular}




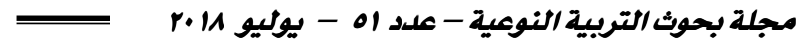

تابع جدول (r) ) لتوصيف اب فوطة تم تنفذها

\begin{tabular}{|c|c|c|}
\hline التوصيف & التصميم قبل الفسيل & ค \\
\hline 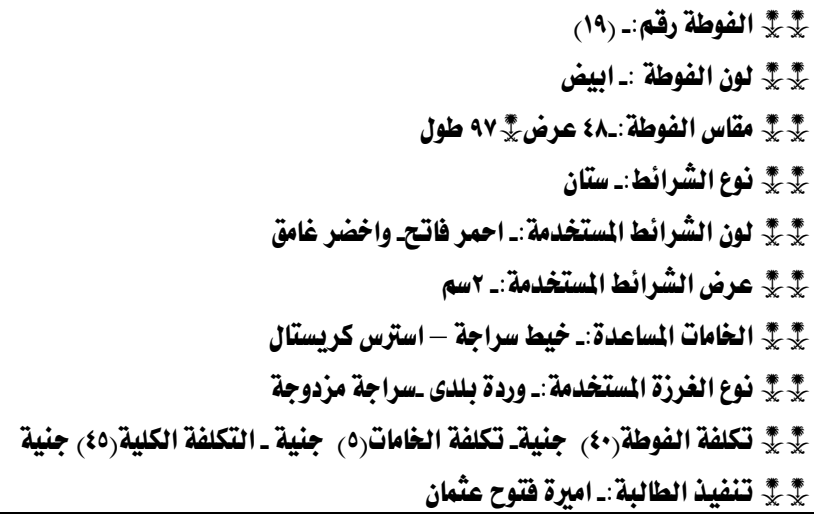 & & -19 \\
\hline 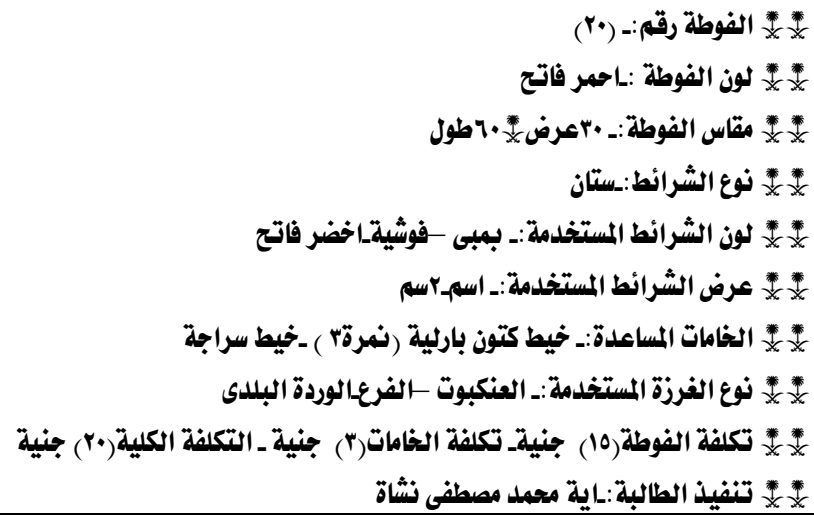 & & $-r \cdot$ \\
\hline 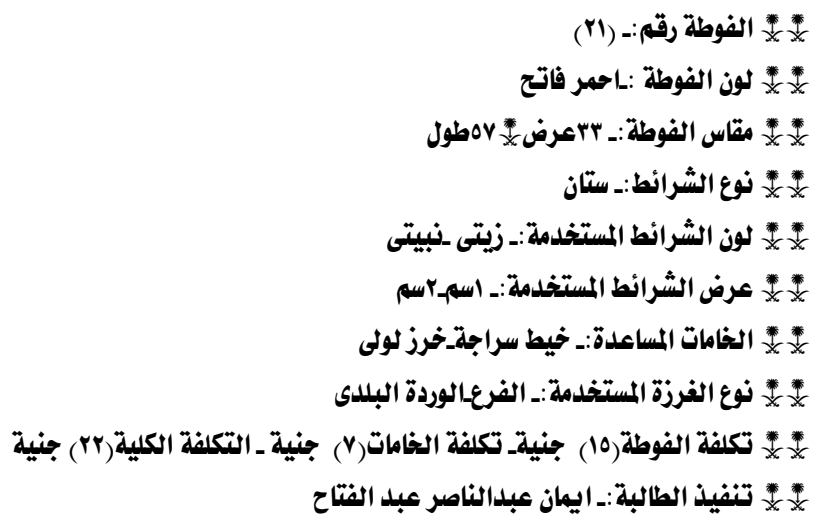 & & $-r$ \\
\hline
\end{tabular}


تابع جدول (r) لتوصيف اب فوطة تم تنفذها

\begin{tabular}{|c|c|c|}
\hline التوصيف & التصميم قبل الفسيل & P \\
\hline 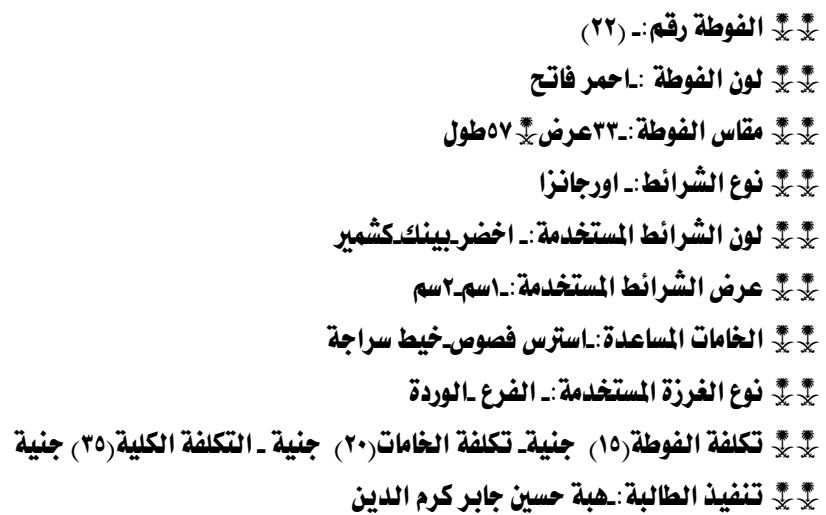 & & $-r r$ \\
\hline 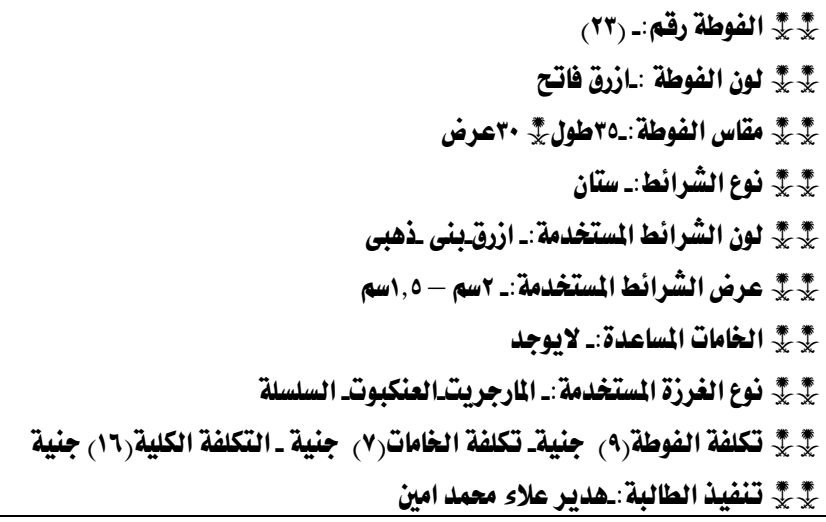 & $\therefore 8$ & -rr \\
\hline 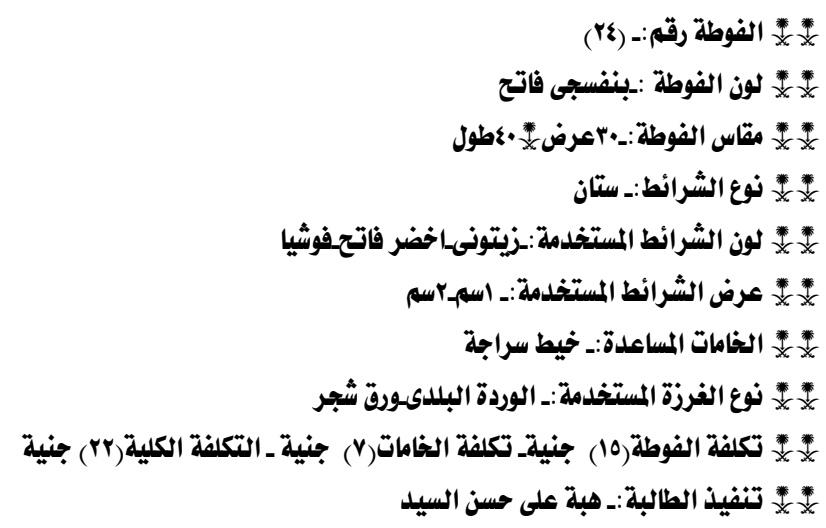 & & $-r \xi$ \\
\hline
\end{tabular}




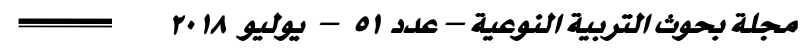

تابع جدول (r) )توصيف اب فوطة تم تنفذها

\begin{tabular}{|c|c|c|}
\hline التوصيف & التصميم قبل الفسيل & 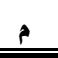 \\
\hline 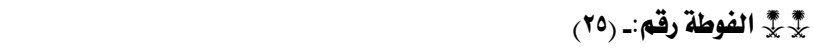 & & - ro \\
\hline 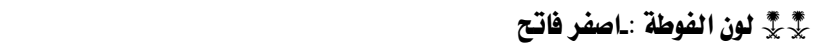 & & \\
\hline |* & & \\
\hline 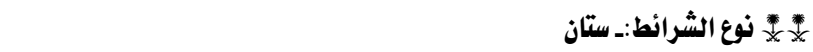 & & \\
\hline 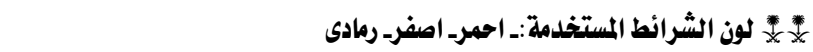 & & \\
\hline 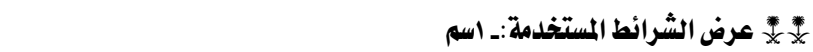 & & \\
\hline 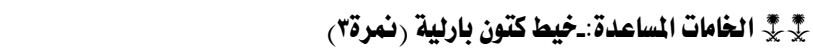 & & \\
\hline ج * * نوع الفرزة المستخدمة:_ غرزة الفرع -غرزة العنكبوت & & \\
\hline \multirow{2}{*}{\multicolumn{3}{|c|}{ 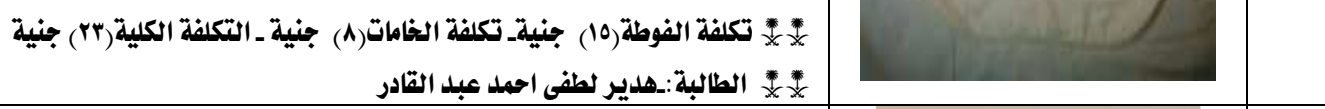 }} \\
\hline & & \\
\hline 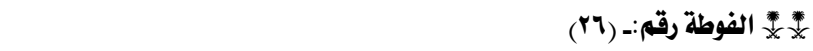 & & $-r q$ \\
\hline 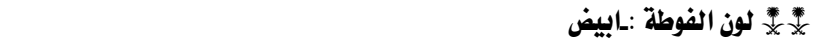 & & \\
\hline 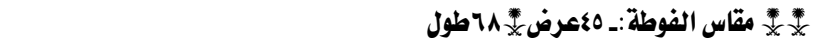 & & \\
\hline 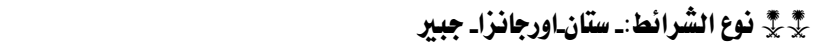 & & \\
\hline 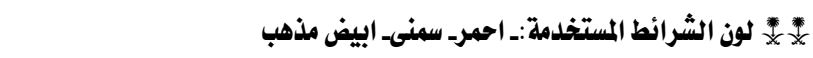 & & \\
\hline 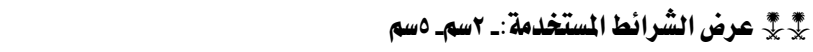 & & \\
\hline 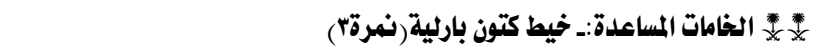 & & \\
\hline 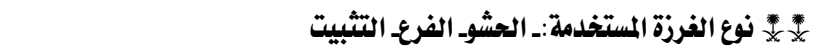 & & \\
\hline \multicolumn{3}{|l|}{ 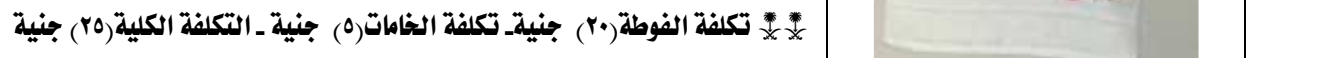 } \\
\hline \multicolumn{3}{|l|}{ 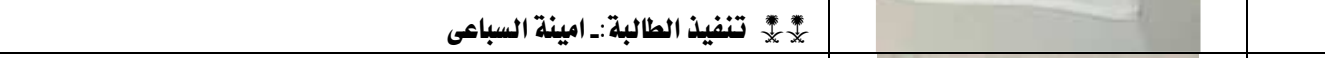 } \\
\hline (TV) & & $-r V$ \\
\hline 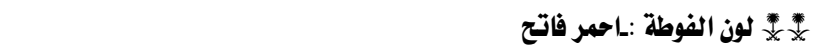 & & \\
\hline 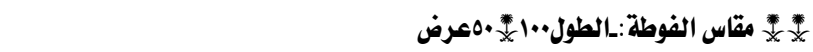 & & \\
\hline 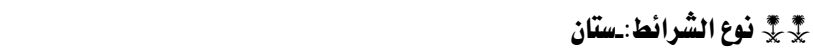 & & \\
\hline 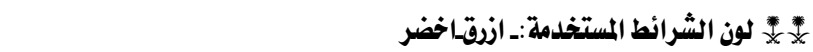 & & \\
\hline 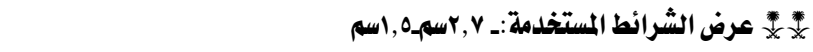 & & \\
\hline 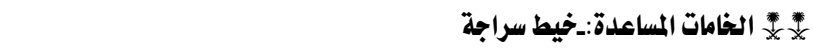 & & \\
\hline ×* نوع الفرزة المستخدمة:_الوردة البلدى_الفرع-المارجريتفرع الشجرة & & \\
\hline 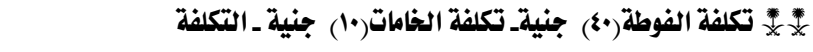 & & \\
\hline 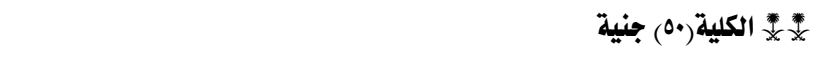 & & \\
\hline 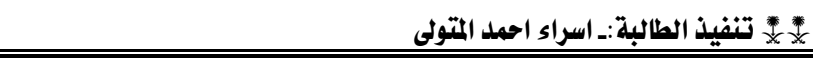 & & \\
\hline
\end{tabular}


تقييم الأداء الوطيفي والجمالي للمفروثات (الفوط) المطرة باسلوب التطريزبشرائط الساتان

تابع جدول (r) لتوصيف اب فوطة تم تنفذها

\begin{tabular}{|c|c|c|}
\hline التوصيف & التصميم قبل الفسيل & a \\
\hline 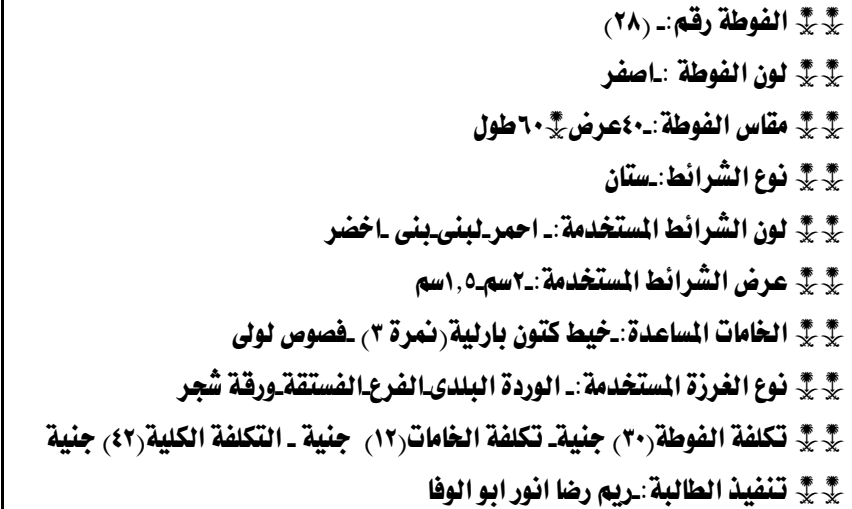 & & -rA \\
\hline 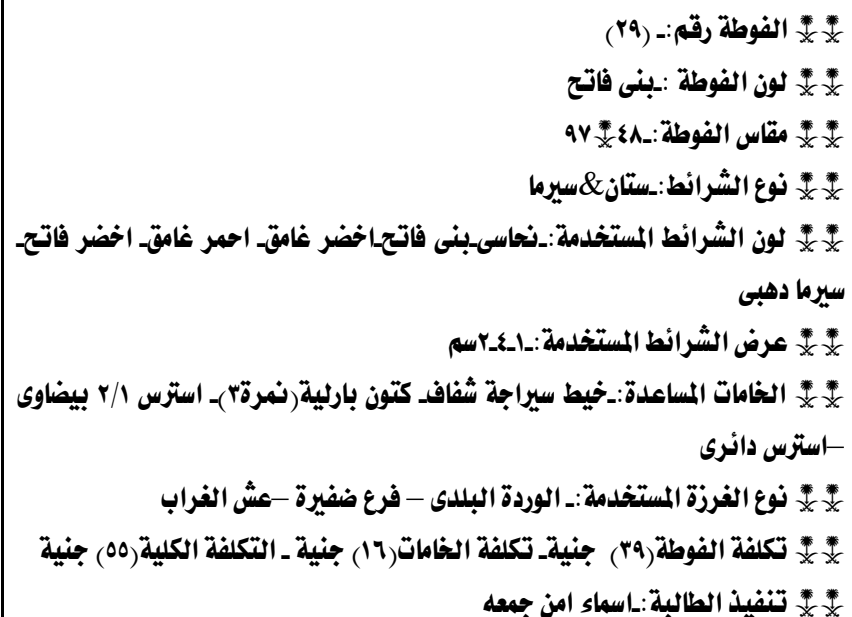 & & - \\
\hline 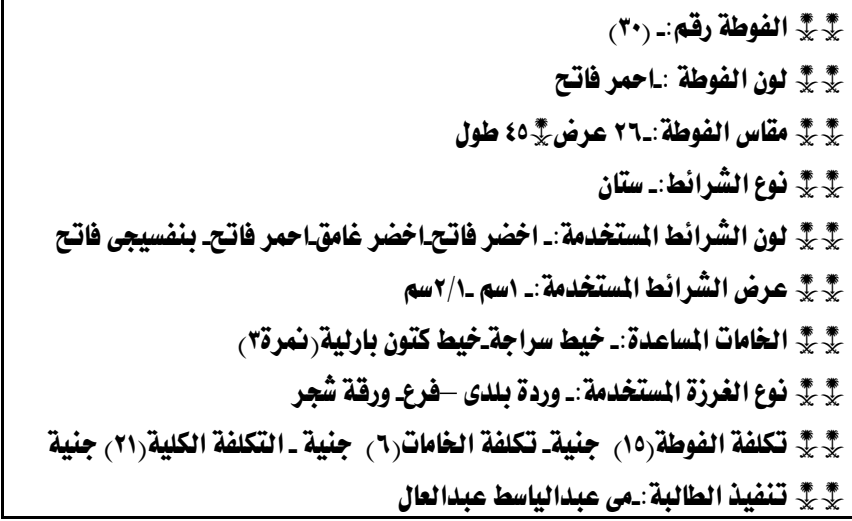 & & - \\
\hline
\end{tabular}




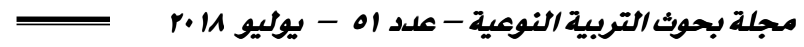

تابع جدول (r) لتوصيف اب فوطة تم تنفذها

\begin{tabular}{|c|c|c|}
\hline التوصيف & التصميم قبل الغسيل & \\
\hline 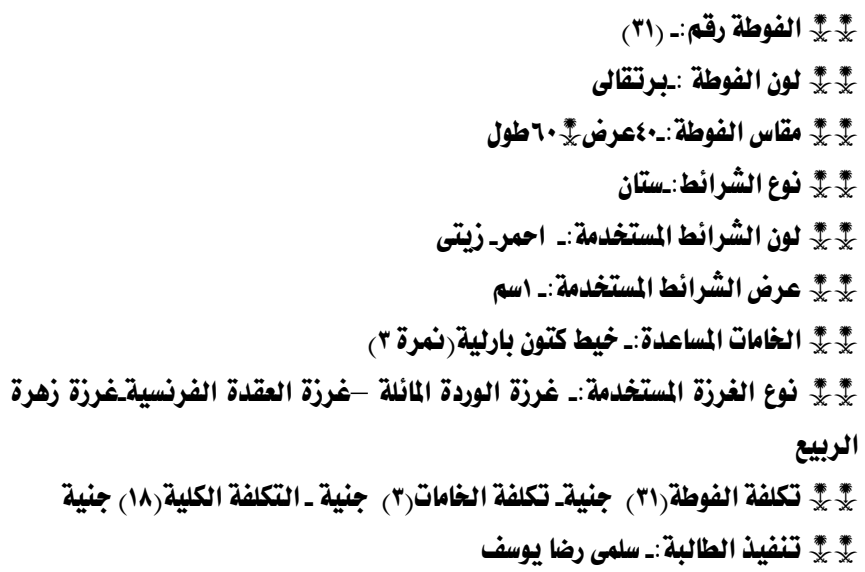 & & - \\
\hline
\end{tabular}

ק- إعداد استمارة لتنفيذ المفروشات المنفذة (الفوط):

اشتملت الاستمارة على ثلاث محاور:الناحية الوظيفية ،الناحية الجمالية ،ناحية جودة

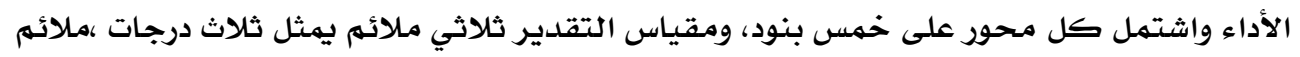

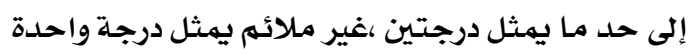

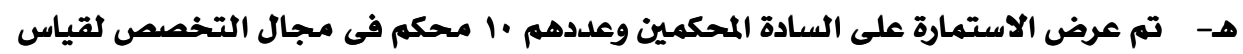
صدق وثبات الاستمارة

وـ تم عرض المفروشات المنفذة (الفوط) على السادة المحكمين وعددهم 11 محكم فى مجال

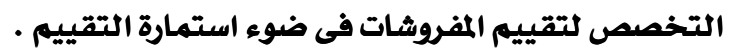

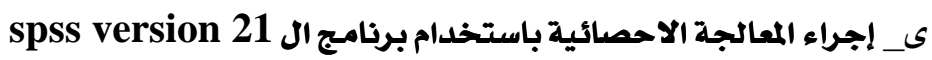

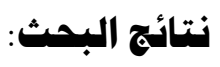

تقنين الأدوات (الصدق والثبات)

أولاً: استبيان تقييم المحكمين للمفروشات المات المنفذة

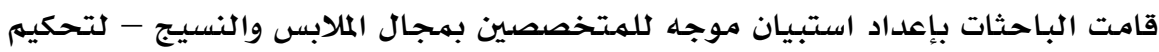

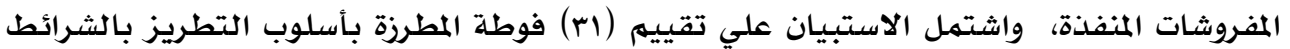

$$
\text { واشتهمل الاستبيان علي ثلاث محاور: }
$$

• المحور الأول: تحقيق الناحية الوظيفية وتتضمن (ه) عبارات.

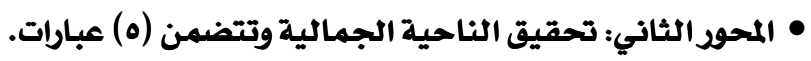


وقد استخدم ميزان تقدير ثلاثي المستويات بحيث تعطي الاجابة مناسب (ثلاث درجات)

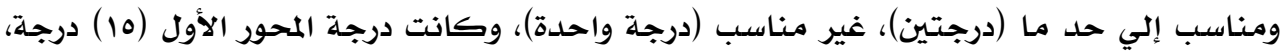

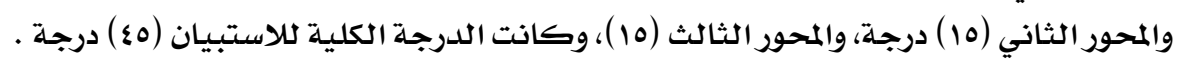
صدق محتوي الاستبيان: صدق المحكمين:

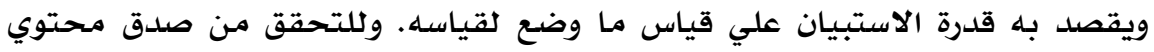

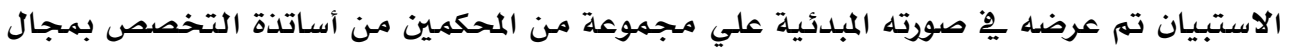

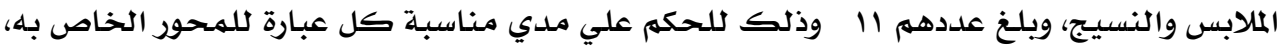
وكذلك صياغة العبارات وتحديد وأضافة أي عبارات مقترحة، وقد تم التعديل بناء علي أراء

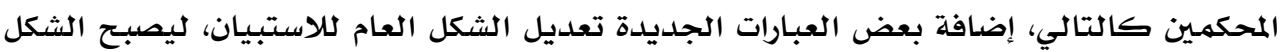
النهائي لها . الميعي

الصداق باستخدام الاتساق الداخلي بين الدرجة الكلية لكل محوروالدرجة الكلية للاستبيان: تم حساب الصدق باستخدام الاتساق الداخلي وذلك بحساب معامل الارتباط (معامل

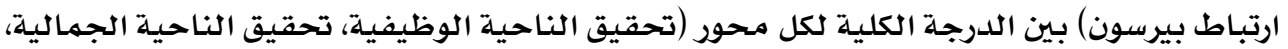
تحقيق جودة الأداء) والدرجة الدين الدرجة الكلية لكل ملاستبيان، والجدول (تحقيق الناحية التالي يوضح ذلكيف: جدول(r): قيم معاملات الارتباط بين درجة كل محور ودرجة الاستبيان

\begin{tabular}{|c|c|c|}
\hline 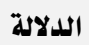 & الارتباط & \\
\hline$\bullet,+1$ & •, 94 & المحور الأول: الناحية الوظيفية \\
\hline$\bullet,+1$ & $\bullet, 91$ & المحور الثاني: تحقيق الناحية الجمالية \\
\hline$\bullet, \cdot 1$ & $\cdot, \wedge 9$ & المحور الثالث: تحقيق جودة الأداء \\
\hline
\end{tabular}

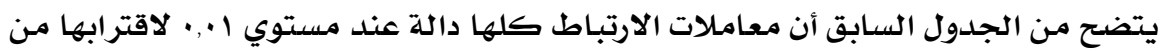

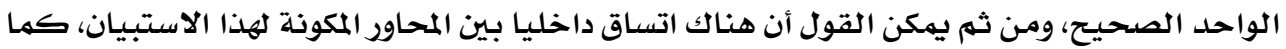

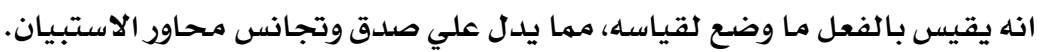
ثبات الاستبيان يقصد بالثبات دقة الاختبار يِّ القياس والملاحظة، وعدم تناقضه مع نفسه، واتساقه

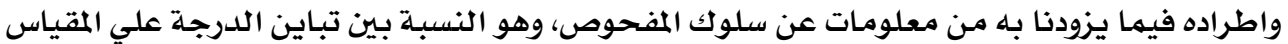

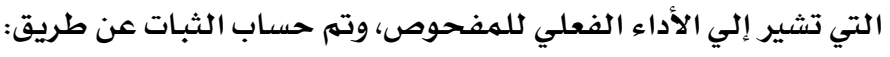

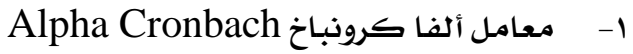

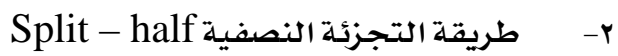




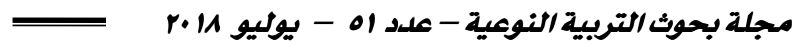

جدول (ع) : قيم معامل الثبات لمحاور الاستبيان

\begin{tabular}{|c|c|c|}
\hline التجزئة النصفية & معامل ألفا & \\
\hline$\cdot$, ArI $\_,$AVr & $\cdot, \wedge \wedge 9$ & المحور الأول: الناحية الوظيفية \\
\hline$\cdot, 9 Y r+\bullet, 199$ & •, AAV & المحور الثاني: تحقيق الناحية الجمالية \\
\hline$\cdot, 9 \$ 0_{-}$, , А१ & •,A91 & المحور الثالث: تحقيق جودة الأداء \\
\hline -, वYq & •, $\wedge \wedge 9$ & ثبات الاستبيان ككل \\
\hline
\end{tabular}

يتضح من الجدول السـابق أن جميع قيم معاملات الثبات، معامل ألفا، التجزئة النصفية،

دالة عند مستوي ا +, • مما يدل علي ثبات الاستبيان.

هناقشة الفروض والنتائج وتفسيرها

الفرض الأول: توجد فروق ذات دلالة إحصائية بين المفروشات (الفوط) المطرزة بأسلوب

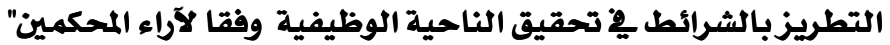

جدول (ه) متوسطات تقييمات المحكمين للمحور الأول من محاور التقييم (تحقيق الناحية الوظيفية) للمفروشات المنفذة

\begin{tabular}{|c|c|c|c|c|c|c|c|c|c|c|c|c|c|c|c|c|}
\hline (17) & (10) & $(\boldsymbol{I})$ & (Ir) & (Ir) & (II) & $(1 \cdot)$ & (9) & $(\boldsymbol{\wedge})$ & $(v)$ & (7) & (0) & (ई) & $\left({ }^{(}\right)$ & $(r)$ & (1) & المؤشرات \\
\hline 28 & 26 & 30 & 27 & 30 & 28 & 26 & 28 & 28 & 30 & 29 & 31 & 28 & 30 & 29 & 30 & بندا \\
\hline 25 & 27 & 29 & 23 & 23 & 26 & 25 & 28 & 25 & 27 & 25 & 26 & 29 & 28 & 26 & 27 & بنده \\
\hline 27 & 27 & 29 & 26 & 22 & 26 & 25 & 23 & 25 & 23 & 26 & 24 & 24 & 25 & 22 & 24 & بندب \\
\hline 23 & 24 & 27 & 22 & 24 & 23 & 25 & 26 & 26 & 27 & 23 & 24 & 27 & 28 & 25 & 26 & بندء \\
\hline 22 & 21 & 27 & 28 & 23 & 22 & 25 & 22 & 24 & 25 & 23 & 23 & 24 & 25 & 22 & 25 & بنده \\
\hline
\end{tabular}

جدول (ه) تابع متوسطات تقييمات المحكمين للمحور الأول من محاور التقييم (تحقيق الناحية الوظيفية) كلمفروشات المنفذة

\begin{tabular}{|c|c|c|c|c|c|c|c|c|c|c|c|c|c|c|c|}
\hline (NI) & $(r \cdot)$ & $(r q)$ & $(\Gamma \Lambda)$ & (YV) & (Yฯ) & (ro) & $(\boldsymbol{Y} \xi)$ & $\left(T^{\top}\right)$ & $(r r)$ & (rI) & $(\Gamma \cdot)$ & (19) & $(\mathrm{IA})$ & (IV) & المؤشرات \\
\hline 27 & 30 & 30 & 32 & 27 & 28 & 32 & 29 & 30 & 32 & 32 & 31 & 29 & 30 & 31 & بندا \\
\hline 26 & 28 & 26 & 30 & 28 & 27 & 26 & 27 & 25 & 28 & 28 & 26 & 26 & 28 & 28 & بندץ \\
\hline 24 & 26 & 24 & 26 & 23 & 23 & 23 & 22 & 23 & 28 & 27 & 24 & 24 & 24 & 29 & بندب \\
\hline 24 & 23 & 22 & 25 & 24 & 23 & 20 & 21 & 24 & 26 & 25 & 22 & 25 & 26 & 20 & بندء \\
\hline 23 & 24 & 25 & 21 & 25 & 21 & 20 & 24 & 22 & 28 & 28 & 27 & 22 & 27 & 20 & بنده \\
\hline
\end{tabular}


تقييم الأداء الوظيفي والجمالمي للمفروثات (الفوط) المطرزة باسلوب التطريزبشرائط الساتان

وللتحقق من هذا الفرض تم حساب تحليل التباين لمتوسط المفروشات المنفذة ِِ تحقيق

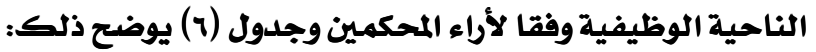

جدول (ج) تحليل التباين لمتوسط تقييم المفروشات المنفذة فِ تحقيق الناحية الوظيفية وفقا لأراء المحكمين

\begin{tabular}{|c|c|c|c|c|c|}
\hline الدلالة & قيمة "ف" & متوسط المربعات & درجة الحرية & مجهوع المربعات & \\
\hline \multirow{3}{*}{.774} & \multirow{3}{*}{.787} & 6.469 & 30 & 194.077 & بين المجموعات \\
\hline & & 8.223 & 124 & 1019.600 & داخل المجموعات \\
\hline & & & 154 & 1213.677 & المجموع \\
\hline
\end{tabular}

تشير نتائج الجدول السابق إلي أن قيمـة (ف) كانت (VAV, •) وهي قيمة غير دالة إحصائيا

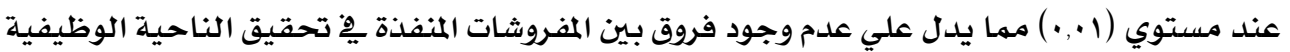

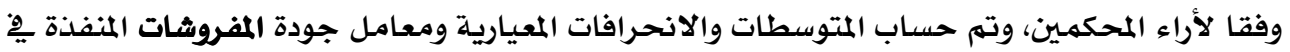

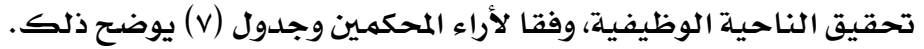




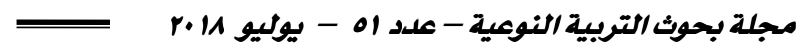

جدول (v) المتوسطات والانحرافات المعيارية ومعامل الجودة للمفروشات المنفذة يُ تحقيق الناحية الوظيفية

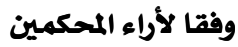

\begin{tabular}{|c|c|c|c|c|}
\hline ترتيب المفروشات & معامل الجودة & الانحراف المعياري & التموسط & الفوط \\
\hline 6 & 80.00 & 2.30 & 26.40 & فوطه | \\
\hline 12 & 75.15 & 2.95 & 24.80 & 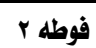 \\
\hline 3 & 82.42 & 2.17 & 27.20 & فوطه بr \\
\hline 6 & 80.00 & 2.30 & 26.40 & 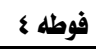 \\
\hline 8 & 77.58 & 3.21 & 25.60 & فوطه ه \\
\hline 10 & 76.36 & 2.49 & 25.20 & فوطه 1 \\
\hline 6 & 80.00 & 2.61 & 26.40 & كوطه V V V \\
\hline 8 & 77.58 & 1.52 & 25.60 & فوطه ه \\
\hline 9 & 76.97 & 2.79 & 25.40 & فوطه 9 \\
\hline 10 & 76.36 & 0.45 & 25.20 & فوطه •1 \\
\hline 11 & 75.76 & 2.45 & 25.00 & فوطه || || || \\
\hline 14 & 73.94 & 3.21 & 24.40 & 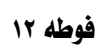 \\
\hline 10 & 76.36 & 2.59 & 25.20 & فوطه זा \\
\hline 1 & 86.06 & 1.34 & 28.40 & فوطه \&| - لما \\
\hline 11 & 75.76 & 2.55 & 25.00 & فوطه 10 \\
\hline 11 & 75.76 & 2.55 & 25.00 & فوطه 19 \\
\hline 8 & 77.58 & 5.22 & 25.60 & | فوطه IV \\
\hline 4 & 81.82 & 2.24 & 27.00 & 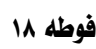 \\
\hline 10 & 76.36 & 2.59 & 25.20 & فوطه 19 \\
\hline 7 & 78.79 & 3.39 & 26.00 & فوطه rr \\
\hline 2 & 84.85 & 2.55 & 28.00 & فوطه Ir \\
\hline 1 & 86.06 & 2.19 & 28.40 & فوطه rr \\
\hline 12 & 75.15 & 3.11 & 24.80 & فوطه rז \\
\hline 13 & 74.55 & 3.36 & 24.60 & 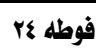 \\
\hline 15 & 73.33 & 5.02 & 24.20 & توطه ro \\
\hline 14 & 73.94 & 2.97 & 24.40 & فوطه YY \\
\hline 9 & 76.97 & 2.07 & 25.40 & فوطه TY \\
\hline 5 & 81.21 & 4.32 & 26.80 & فوطه شT \\
\hline 9 & 76.97 & 2.97 & 25.40 & فوطه جr \\
\hline 7 & 79.39 & 2.86 & 26.20 & فوطه •r \\
\hline 12 & 75.15 & 1.64 & 24.80 & فوطه ات \\
\hline
\end{tabular}




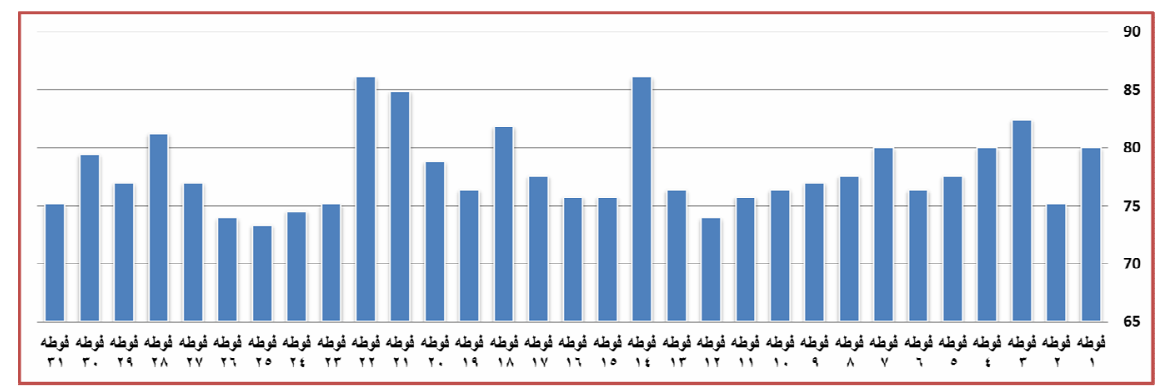

ثكل (1) يوضع معامل الجودة للمفروثـات المنفذة يِ تحقيق الناحية الوظيفية وفقا لأراء المحكمين

$$
\text { من الجدول (v) والشكل (1) يتضح أن: }
$$

فنجد أن أفضل المفروشات المنفذة يف تحقيق الناحية الوظيفية، وفقا لأراء المحكمـين

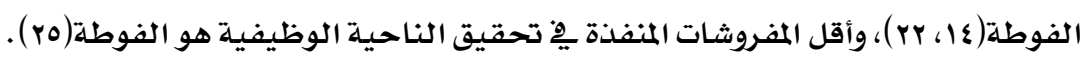

الفرض الثاني: توجد فروق ذات دلاله إحصائية بين المفروشات (الفوط) المطرزة بأسلوب التطريز بالشرائط يخ تحقيق الناحية الجمالية وفقا لآراء المحكمـين"

جدول (^) متوسطات تقييمات المحكمين للمحور الثاني من محاور التقييم (تحقيق الناحية الجمالية) للمفروشات المنفذة

\begin{tabular}{|c|c|c|c|c|c|c|c|c|c|c|c|c|c|c|c|c|}
\hline (17) & (10) & (1) & (Ir) & (Ir) & (II) & (1.) & (9) & $(\boldsymbol{A})$ & $(v)$ & (1) & (0) & (₹) & (广) & $(r)$ & (1) & المؤشرات \\
\hline 27 & 29 & 30 & 28 & 29 & 28 & 27 & 25 & 29 & 32 & 27 & 26 & 26 & 23 & 25 & 26 & بندا \\
\hline 25 & 21 & 29 & 22 & 26 & 27 & 27 & 23 & 27 & 28 & 22 & 22 & 21 & 27 & 23 & 26 & بندا \\
\hline 19 & 28 & 23 & 20 & 25 & 22 & 24 & 24 & 28 & 23 & 21 & 22 & 23 & 24 & 26 & 25 & بندץ \\
\hline 24 & 24 & 25 & 25 & 25 & 23 & 20 & 22 & 26 & 25 & 20 & 22 & 22 & 27 & 24 & 25 & بندء \\
\hline 23 & 27 & 23 & 23 & 24 & 24 & 24 & 24 & 25 & 24 & 22 & 22 & 23 & 25 & 23 & 24 & بنده \\
\hline
\end{tabular}

جلدول (^) تابع متوسطات تقييمات المحكمين للمحور الثاني من محاور التقييم (تحقيق الناحية الجمالية) للمفروثات المنفذة

\begin{tabular}{|c|c|c|c|c|c|c|c|c|c|c|c|c|c|c|c|}
\hline (WI) & $(\Gamma \cdot)$ & $(r 9)$ & $(Y \wedge)$ & (TV) & (Y7) & (ro) & $(\bar{\xi})$ & (YT) & $(M Y)$ & (ri) & $\left(r^{*}\right)$ & (19) & $(\mathrm{IA})$ & (IV) & المؤشرات \\
\hline 28 & 30 & 22 & 32 & 24 & 29 & 28 & 25 & 27 & 32 & 29 & 28 & 27 & 26 & 33 & بندا \\
\hline 26 & 29 & 22 & 27 & 24 & 28 & 24 & 28 & 28 & 29 & 28 & 27 & 24 & 23 & 29 & بندم \\
\hline 22 & 26 & 23 & 24 & 25 & 23 & 24 & 25 & 22 & 30 & 26 & 23 & 20 & 26 & 24 & بندا \\
\hline 25 & 26 & 26 & 27 & 27 & 25 & 24 & 23 & 24 & 28 & 24 & 25 & 19 & 23 & 29 & بندى \\
\hline 24 & 25 & 23 & 26 & 24 & 22 & 27 & 23 & 25 & 28 & 27 & 21 & 21 & 23 & 27 & بنده \\
\hline
\end{tabular}




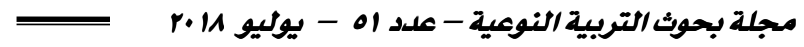

وللتحقق من هذا الفرض تم حساب تحليل التباين لمتوسط المفروشات المنفذة ِِ تحقيق

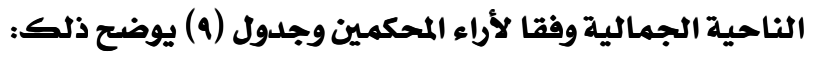
جدول (9) تحليل التباين لمتوسط تقييم المفروشات المنفذة يِّ تحقيق الناحية الجمالية وفقا لأراء المحكمين

\begin{tabular}{|c|c|c|c|c|c|}
\hline الدلالة & قيمة "ف" & متوسط المربعات & درجة الحرية & مجموع المربعات & \\
\hline \multirow{3}{*}{.000} & \multirow{3}{*}{2.488} & 14.438 & 30 & 433.135 & بين المجموعات \\
\hline & & 5.803 & 124 & 719.600 & داخل المجموعات \\
\hline & & & 154 & 1152.735 & المجموع \\
\hline
\end{tabular}

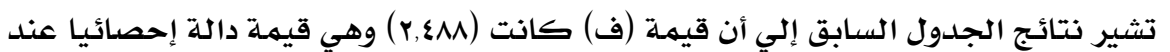

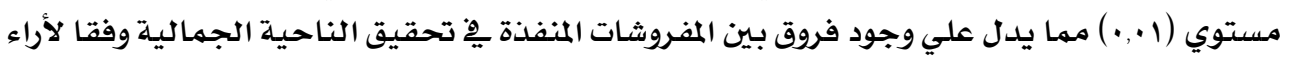

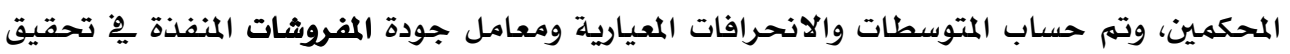

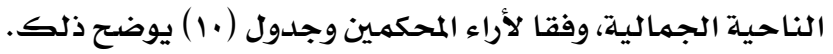
جدول ( ـ ) المتوسطات والانحرافات المعيارية ومعامل الجودة للمفروشات المنفذة يِّ تحقيق الناحية الجمالية

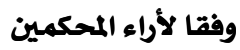

\begin{tabular}{|c|c|c|c|c|}
\hline ترتيب المفروشات & معامل الجودة & الانحراف المعياري & المتوسط & الفوط \\
\hline 10 & 76.36 & 0.84 & 25.20 & فوطه | \\
\hline 14 & 73.33 & 1.30 & 24.20 & فوطه r \\
\hline 10 & 76.36 & 1.79 & 25.20 & فوطه ب \\
\hline 17 & 69.70 & 1.87 & 23.00 & فوطه ؟ \\
\hline 18 & 69.09 & 1.79 & 22.80 & فوطه 0 \\
\hline 19 & 67.88 & 2.70 & 22.40 & فوطه I \\
\hline 6 & 80.00 & 3.65 & 26.40 & فوطه v \\
\hline 4 & 81.82 & 1.58 & 27.00 & فوطه 1 \\
\hline 15 & 71.52 & 1.14 & 23.60 & فوطه 9 \\
\hline 13 & 73.94 & 2.88 & 24.40 & فوطه 1. \\
\hline 12 & 75.15 & 2.59 & 24.80 & فوطه 11 \\
\hline 8 & 78.18 & 1.92 & 25.80 & فوطه ri \\
\hline 15 & 71.52 & 3.05 & 23.60 & فوطه 14 \\
\hline 7 & 78.79 & 3.32 & 26.00 & فوطه \&1 \\
\hline 8 & 78.18 & 3.27 & 25.80 & فوطه 10 \\
\hline 15 & 71.52 & 2.97 & 23.60 & فوطه 17 \\
\hline 2 & 86.06 & 3.29 & 28.40 & فوطه IV \\
\hline 14 & 73.33 & 1.64 & 24.20 & فوطه 11 \\
\hline 20 & 67.27 & 3.27 & 22.20 & فوطه 19 \\
\hline 12 & 75.15 & 2.86 & 24.80 & فوطه +r \\
\hline
\end{tabular}




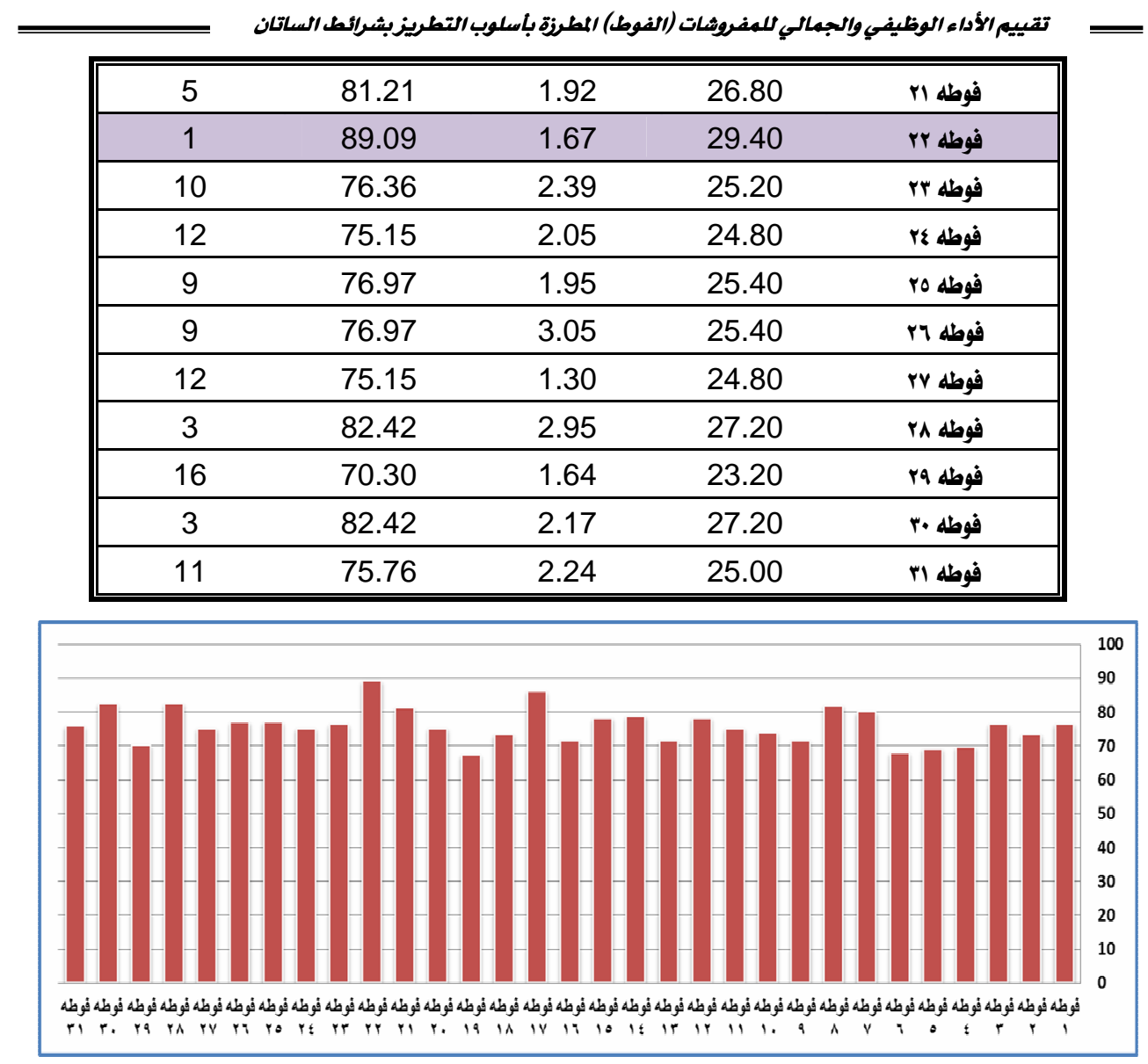

شكل (Y) يوضح معامل الجودة للمفروشات المنفذة فِ تحقيق الناحية الجمالية وفقا لأراء المحكمين.

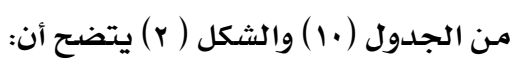

فنجد أن أفضل المفروشات المنفذة ِِّ تحقيق الناحية الجمالية، وفقا لأراء المحكمين

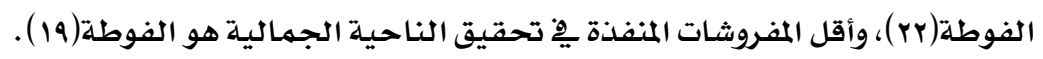




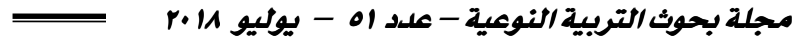

الفرض الثالث: توجد فروق ذات دلالة إحصائية بين المفروشات (الفوط) المطرزة بأسلوب

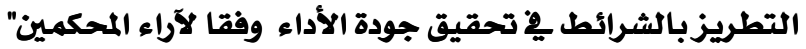

جدول (11) متوسطات تقييمات المحكمين للمحور الثالث من محاور التقييم (تحقيق جودة الأداء) للمفروشات

المنفذة

\begin{tabular}{|c|c|c|c|c|c|c|c|c|c|c|c|c|c|c|c|c|}
\hline (17) & (10) & $(\mathbf{I})$ & $(I r)$ & $(I r)$ & (II) & (1.) & (9) & $(\mathbf{A})$ & $(v)$ & (7) & $(0)$ & $(\mathfrak{\xi})$ & $(\boldsymbol{\nu})$ & $(r)$ & (1) & المؤشرات \\
\hline 28 & 30 & 29 & 25 & 28 & 28 & 24 & 27 & 30 & 28 & 28 & 32 & 24 & 30 & 26 & 27 & بندا \\
\hline 29 & 27 & 28 & 20 & 24 & 25 & 24 & 26 & 27 & 27 & 28 & 24 & 24 & 30 & 27 & 32 & بندץ \\
\hline 21 & 24 & 25 & 23 & 23 & 26 & 24 & 23 & 25 & 26 & 19 & 26 & 23 & 27 & 24 & 29 & بندا \\
\hline 23 & 24 & 22 & 23 & 26 & 24 & 22 & 25 & 25 & 24 & 22 & 22 & 23 & 25 & 21 & 27 & بندى \\
\hline 21 & 26 & 26 & 23 & 25 & 24 & 24 & 24 & 26 & 26 & 24 & 27 & 23 & 25 & 25 & 22 & بنده \\
\hline
\end{tabular}

جدول (1) تابع متوسطات تقييمات المحكمين للمحور الثالث من محاور التقييم (تحقيق جودة الأداء) للمفروثات المنفذة

\begin{tabular}{|c|c|c|c|c|c|c|c|c|c|c|c|c|c|c|c|}
\hline (NI) & $\left({ }^{* *}\right)$ & $(r q)$ & $(T \Lambda)$ & $(r V)$ & $(\Gamma q)$ & (ro) & $(\bar{\xi})$ & $\left(r^{r}\right)$ & $(r r)$ & (rI) & $\left(r_{*}\right)$ & $(19)$ & $(\mathrm{IA})$ & (IV) & لمؤشرات \\
\hline 28 & 28 & 29 & 29 & 27 & 32 & 25 & 27 & 27 & 29 & 31 & 29 & 29 & 29 & 29 & بندا \\
\hline 27 & 25 & 28 & 29 & 27 & 26 & 28 & 23 & 24 & 26 & 24 & 26 & 27 & 24 & 28 & بندا \\
\hline 23 & 24 & 23 & 22 & 23 & 21 & 21 & 23 & 27 & 33 & 23 & 25 & 25 & 26 & 21 & بندب \\
\hline 25 & 24 & 23 & 23 & 23 & 24 & 26 & 22 & 22 & 28 & 25 & 22 & 21 & 24 & 25 & بندء \\
\hline 26 & 28 & 23 & 26 & 24 & 27 & 23 & 22 & 23 & 28 & 26 & 23 & 22 & 23 & 28 & بنده \\
\hline
\end{tabular}

وللتحقق من هذا الفرض تم حساب تحليل التباين لمتوسط المفروشات المنفذة يِّ تحقيق

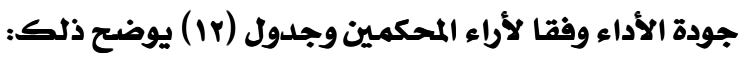

جدول (r) تحليل التباين لمتوسط تقييم المفروشات المنفذة ـِ تحقيق جودة الأداء وفقا لأراء المحكمين

\begin{tabular}{|c|c|c|c|c|c|}
\hline الدلالة & قيعة "ف" & متوسط المربعات & درجة الحرية & مجموع المربعات & \\
\hline \multirow{3}{*}{.303} & \multirow{3}{*}{1.139} & 8.068 & 30 & 242.039 & بين المجموعات \\
\hline & & 7.081 & 124 & 878.000 & داخل المجموعات \\
\hline & & & 154 & 1120.039 & المجموع \\
\hline
\end{tabular}

تشير نتائج الجدول السابق إلي أن قيمة (ف) كانت (Y,§ ) وهي قيمة غير دالة إحصائيا

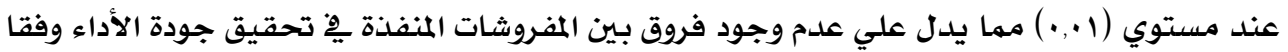

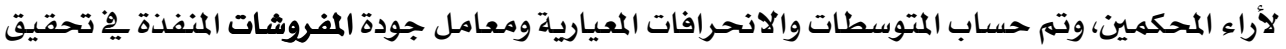

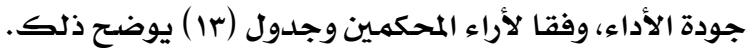


تقييم الأداء الوظيفي والجمالمي للمفروثات (الفوط) المطرزة باسلوب التطريزبشرائط الساتان

جدول (rا ) المتوسطات والانحرافات المعيارية ومعامل الجودة للمفروشات المنفذة فِ تحقيق جودة الأداء وفقا لأراء المحكمـين

\begin{tabular}{|c|c|c|c|c|}
\hline ترتيب المفروشات & معامل الجودة & الانحراف المعياري & المتوسط & الفوط \\
\hline 2 & 83.03 & 3.65 & 27.40 & فوطه 1 \\
\hline 11 & 74.55 & 2.30 & 24.60 & فوطه r \\
\hline 2 & 83.03 & 2.51 & 27.40 & فوطه بr \\
\hline 14 & 70.91 & 0.55 & 23.40 & فوطه ؟ \\
\hline 4 & 79.39 & 3.77 & 26.20 & فوطه 0 \\
\hline 13 & 73.33 & 3.90 & 24.20 & فوطه 7 \\
\hline 4 & 79.39 & 1.48 & 26.20 & فوطه V \\
\hline 3 & 80.61 & 2.07 & 26.60 & فوطه 1 \\
\hline 9 & 75.76 & 1.58 & 25.00 & فوطه 9 \\
\hline 14 & 71.52 & 0.89 & 23.60 & فوطه 1. \\
\hline 7 & 76.97 & 1.67 & 25.40 & فوطه 11 \\
\hline 8 & 76.36 & 1.92 & 25.20 & فوطه \\
\hline 16 & 69.09 & 1.79 & 22.80 & فوطه II \\
\hline 5 & 78.79 & 2.74 & 26.00 & فوطه \&1 \\
\hline 4 & 79.39 & 2.49 & 26.20 & فوطه 10 \\
\hline 12 & 73.94 & 3.85 & 24.40 & فوطه 17 \\
\hline 4 & 79.39 & 3.27 & 26.20 & فوطه IV \\
\hline 8 & 76.36 & 2.39 & 25.20 & فوطه 11 \\
\hline 10 & 75.15 & 3.35 & 24.80 & فوطه 19 \\
\hline 9 & 75.76 & 2.74 & 25.00 & فوطه r r \\
\hline 6 & 78.18 & 3.11 & 25.80 & فوطه II \\
\hline 1 & 87.27 & 2.59 & 28.80 & فوطه rr \\
\hline 11 & 74.55 & 2.30 & 24.60 & فوطه بrr \\
\hline 14 & 70.91 & 2.07 & 23.40 & فوطه \&ץ \\
\hline 11 & 74.55 & 2.70 & 24.60 & فوطه ro \\
\hline 5 & 78.79 & 4.06 & 26.00 & فوطه 7 Tو \\
\hline 10 & 75.15 & 2.05 & 24.80 & فوطه PV \\
\hline 6 & 78.18 & 3.27 & 25.80 & فوطه YA \\
\hline 8 & 76.36 & 3.03 & 25.20 & فوطه ra \\
\hline 6 & 78.18 & 2.05 & 25.80 & فوطه +r \\
\hline 6 & 78.18 & 1.92 & 25.80 & فوطه IT \\
\hline
\end{tabular}




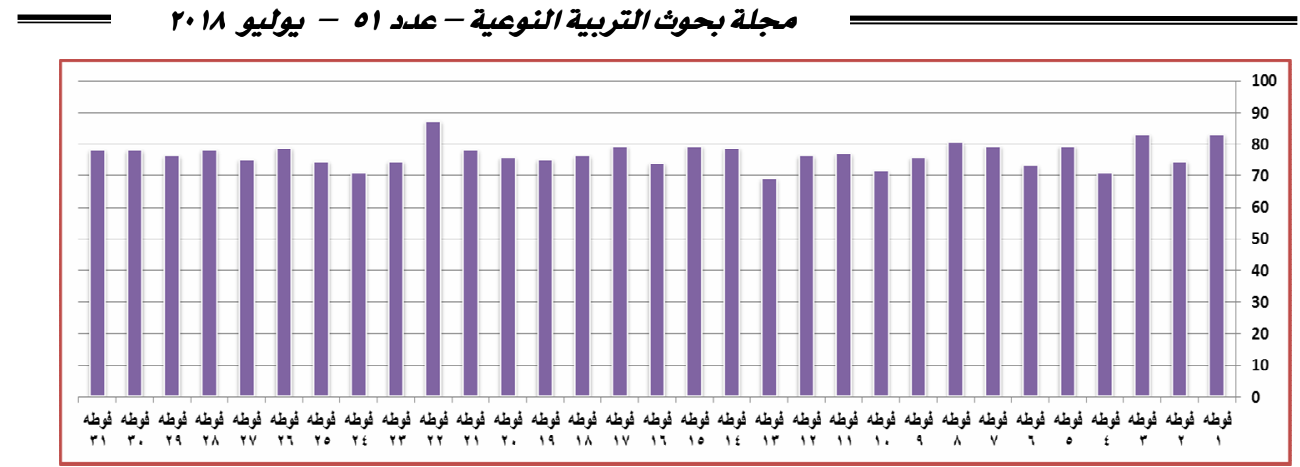

شكل (r) يوضح معامل الجودة للمفروشات المنفذة يُ تحقيق جودة الأداء وفقا لأراء المحكمين.

$$
\text { من الجدول (r) والشكل (r) يتضـح أن: }
$$

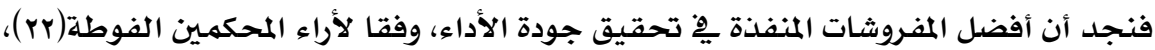

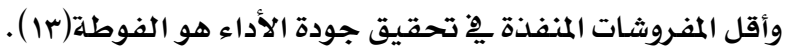

الفرض الرابع: توجد فروق ذات دلالة إحصائية بين المفروثات المنفذة مِ تحقيق جوانب

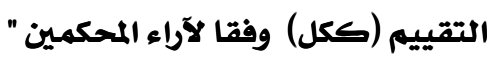

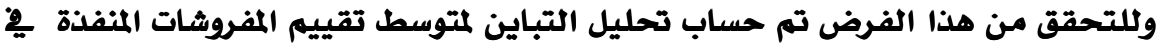

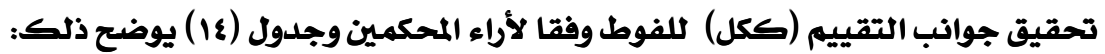

جدول (\&) تحليل التباين لمتوسط تقييم المفروشات المنفذة ِِ تحقيق جوانب التقييم (ككل) وفقا لأراء

\begin{tabular}{|c|c|c|c|c|c|}
\hline الدلالة & قيمة "ف" & متوسط المربعات & درجة الحرية & مجموع المربعات & جوانب التقييي \\
\hline \multirow{3}{*}{.000} & \multirow{3}{*}{2.880} & 19.476 & 30 & 584.267 & بين المجموعات \\
\hline & & 6.763 & 434 & 2935.333 & داخل المجموعات \\
\hline & & & 464 & 3519.600 & المجموع \\
\hline
\end{tabular}
المحكمين

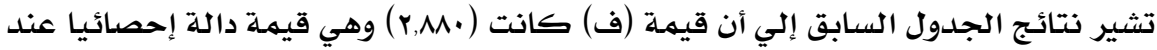

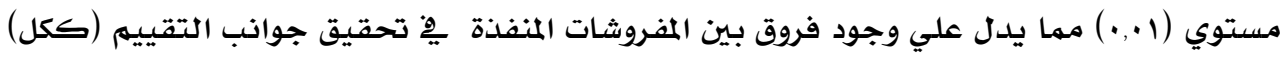

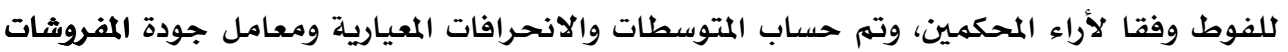

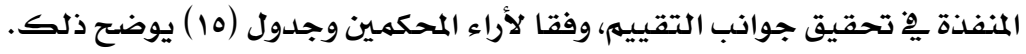




\begin{tabular}{|c|c|c|c|c|}
\hline \multicolumn{5}{|c|}{ 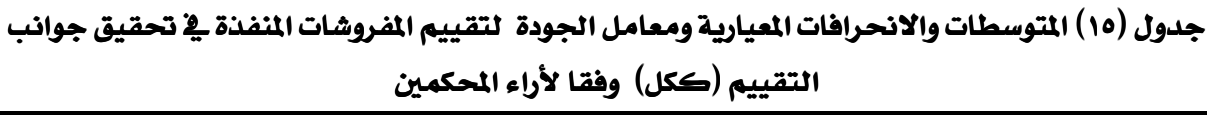 } \\
\hline ترتيب المفروشات & معامل الجودة & الانحراف المعياري & المتوسط & الفوط \\
\hline 8 & 79.80 & 2.53 & 26.33 & فوطه 1 \\
\hline 20 & 74.34 & 2.13 & 24.53 & فوطه r \\
\hline 6 & 80.61 & 2.26 & 26.60 & فوطه r| \\
\hline 23 & 73.54 & 2.25 & 24.27 & فوطه ؛ \\
\hline 16 & 75.35 & 3.20 & 24.87 & فوطه ه \\
\hline 25 & 72.53 & 3.10 & 23.93 & فوطه 7 \\
\hline 8 & 79.80 & 2.53 & 26.33 & فوطه V \\
\hline 7 & 80.00 & 1.72 & 26.40 & فوطه 1 \\
\hline 18 & 74.75 & 1.99 & 24.67 & فوطه 9 \\
\hline 21 & 73.94 & 1.76 & 24.40 & فوطه . \\
\hline 14 & 75.96 & 2.12 & 25.07 & فوطه 11 \\
\hline 13 & 76.16 & 2.33 & 25.13 & فوطه ri \\
\hline 26 & 72.32 & 2.56 & 23.87 & فوطه ri \\
\hline 3 & 81.21 & 2.68 & 26.80 & فوطه \&1 \\
\hline 9 & 77.78 & 2.64 & 25.67 & فوطه 10 \\
\hline 22 & 73.74 & 2.99 & 24.33 & فوطه 17 \\
\hline 4 & 81.01 & 3.94 & 26.73 & فوطه IV \\
\hline 10 & 77.17 & 2.29 & 25.47 & فوطه |A \\
\hline 24 & 72.93 & 3.17 & 24.07 & فوطه 19 \\
\hline 11 & 76.57 & 2.84 & 25.27 & فوطه .r \\
\hline 2 & 81.41 & 2.56 & 26.87 & فوطه II \\
\hline 1 & 87.47 & 2.07 & 28.87 & فوطه r \\
\hline 16 & 75.35 & 2.45 & 24.87 & فوطه rr| \\
\hline 23 & 73.54 & 2.46 & 24.27 & فوطه §Y \\
\hline 17 & 74.95 & 3.26 & 24.73 & فوطه ro \\
\hline 11 & 76.57 & 3.22 & 25.27 & فوطه Yr \\
\hline 15 & 75.76 & 1.73 & 25.00 & فوطه rV \\
\hline 6 & 80.61 & 3.36 & 26.60 & فوطه \\
\hline 19 & 74.55 & 2.64 & 24.60 & فوطه \\
\hline 7 & 80.00 & 2.29 & 26.40 & فوطه +rr \\
\hline 12 & 76.36 & 1.86 & 25.20 & فوطه Ir \\
\hline
\end{tabular}




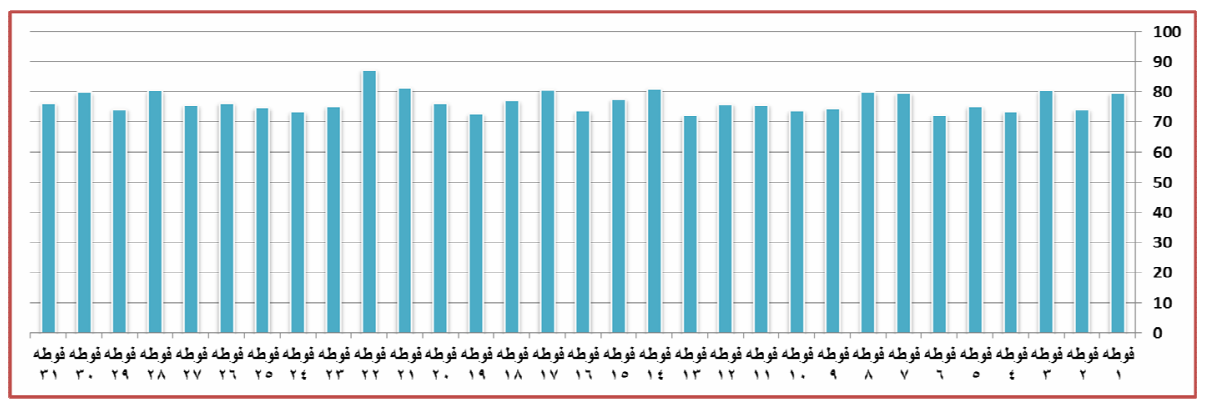

شكل (ع) يوضح معامل الجودة للمفروشات المنفذة يـ تحقيق جوانب التقييم (ككل) وفقا لأراء المحكمين.

$$
\text { من الجدول (10 ) والشكل (ع ) يتضح أن: }
$$

فنجلد أن أفضل المفروشات المنفذة يخ تحقيق جوانب التقييه (ككل)، وفقا لأراء المحكمـين

الفوطة(rr)، وأقل المفروشات المنفذة يْ تحقيق جودة الأداء هو الفوطة (rات ).

الفرض الخامس: توجد فروق ذات دلالة إحصائية بين محاور تقييم المفروشات المنفذة

وفقا لآراء المحكمـين "

وللتحقق من هذا الفرض تم حساب تحليل التباين لمتوسط تقييم محاور تقييم المفروشات

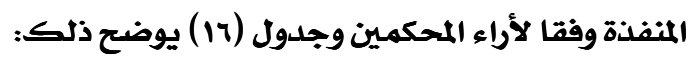

جلدول (17) تحليل التباين لمتوسط تقييم المفروشات المنفذة وفقا لأراء المحكمين

\begin{tabular}{|c|c|c|c|c|c|}
\hline الدلالة & قيمة للّففلله & متوسط المربعات & درجة الحرية & مجموع المربعات & محاور التقييي \\
\hline \multirow{3}{*}{.012} & \multirow{3}{*}{2.196} & 16.574 & 2 & 33.148 & بين المجموعات \\
\hline & & 7.546 & 462 & 3486.452 & داخل المجموعات \\
\hline & & & 464 & 3519.600 & المجموع \\
\hline
\end{tabular}

تشير نتائج الجدول السـابق إلي أن قيمة (ف) كانت (r,197) وهي قيمة دالة إحصائيا عند

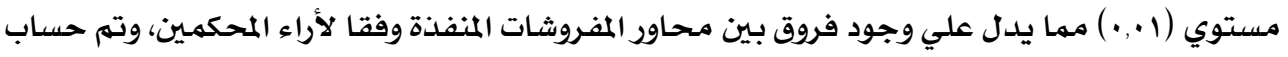
المتوسطات والانحرافات المعياريـة ومعامل جودة لمحاور المفروشات المنفذة وفقا لأراء المحكمـين وجدول

$$
\text { (IV) }
$$

جدول (IV) المتوسطات والانحرافات المعيارية ومعامل الجودة لتقييم محاور المفروثات المنفذة وفقا لأراء

\begin{tabular}{|c|c|c|c|c|}
\hline ترتيب المحاور & معامل الجودة & الانحراف المعياري & المتوسط & المحور \\
\hline 1 & 78.01 & 2.81 & 25.74 & تحقيق الناحية الوظيفية \\
\hline 3 & 76.03 & 2.74 & 25.09 & تحقيق الناحية الجمالية \\
\hline 2 & 76.87 & 2.70 & 25.37 & تحقيق جودة الأداء \\
\hline
\end{tabular}
المحكمين 


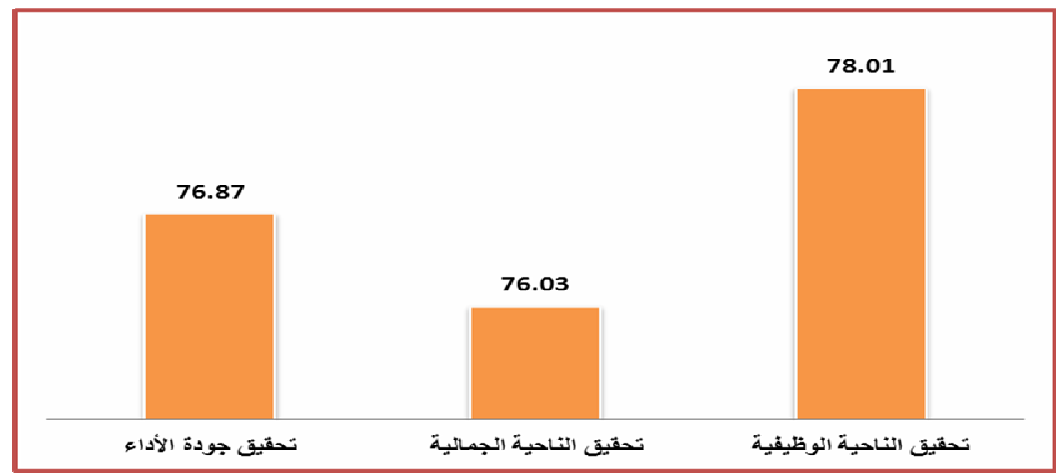

شكل (0) يوضح معامل الجودة لمحاور المفروشات المنفذة وفقا لأراء المحكمين.

من الجدول (IV) والشكل (o) يتضح أن: أفضل المحاور تحقيق الناحية الوظيفية، يليه تحقيق جودة الأداء، يليه تحقيق الناحية الجمالية.

التتوصيات : التوديق جودة

ا ـ الربط بين الأداء الوظيفي والجمالي يِ المفروشات وبين متطلبات التطريز بالشرائط .

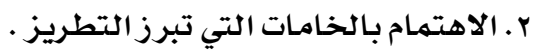

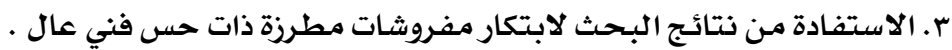

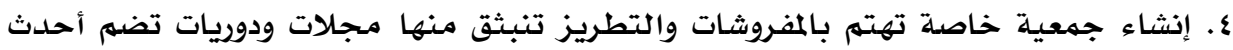

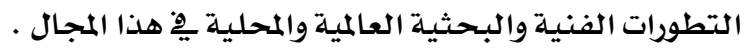

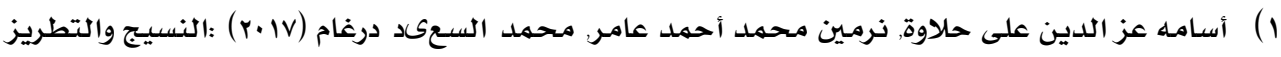

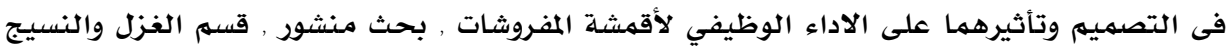

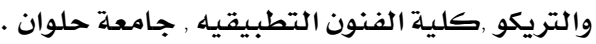

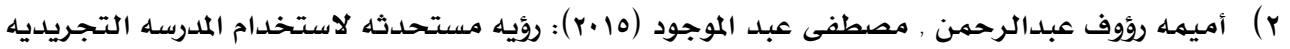

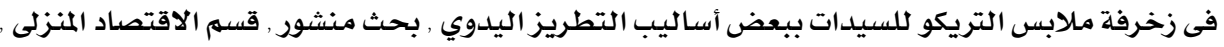

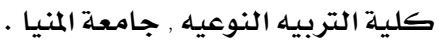

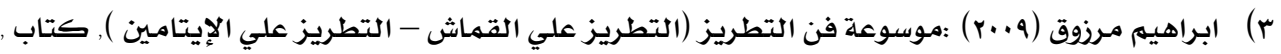
مكتبة ابن سينا , القاهرة , ط (1) ).

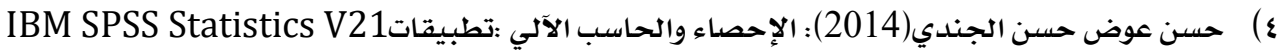
مكتبة الأنجلو المصرية ، القاهرة ، الطبعة الأولي. 


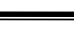

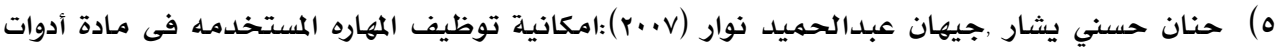

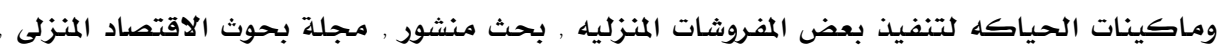

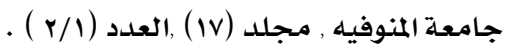

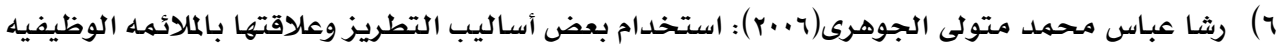

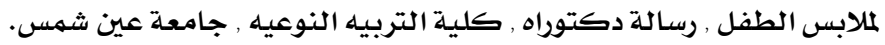

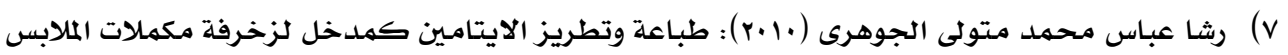

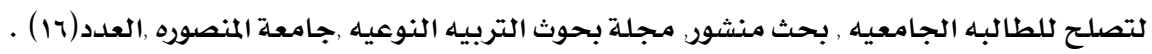

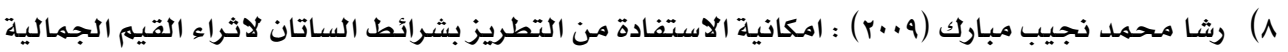

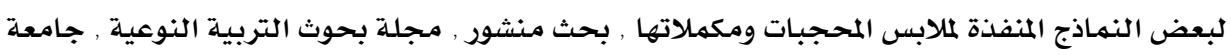

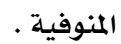

ه) سامية محمد الطوبشي (1999) : معرض الاستفادة من عوادم الميتراج ومصانع الملابس الجاهزة ِِّ انتاج

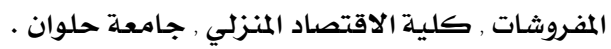

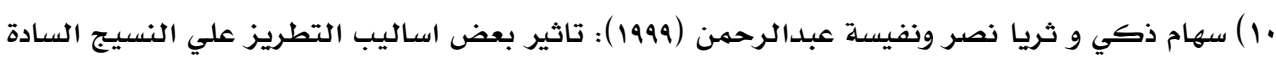

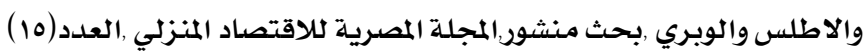

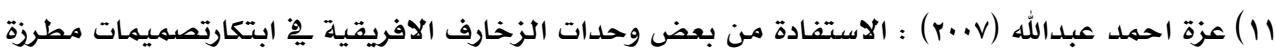

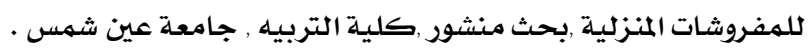

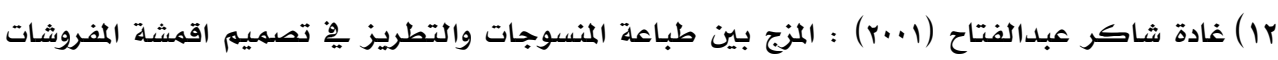

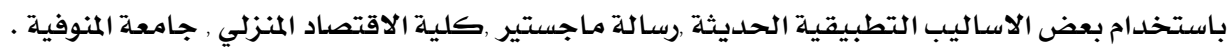

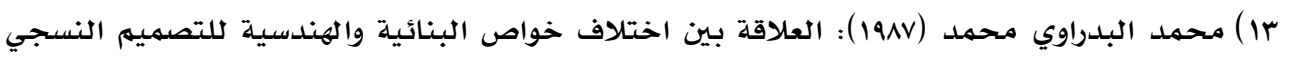

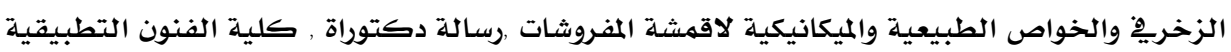
جامعة حلوان .

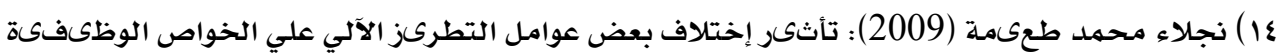

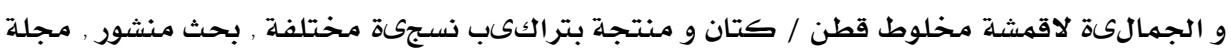
علومو فنون , جامعة حلوان , 17 اكتوبر.

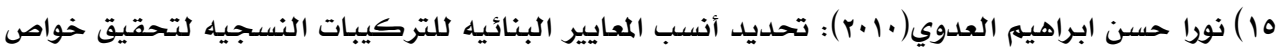

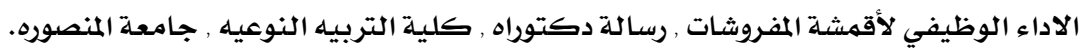

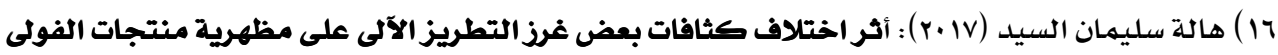

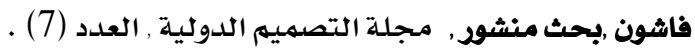

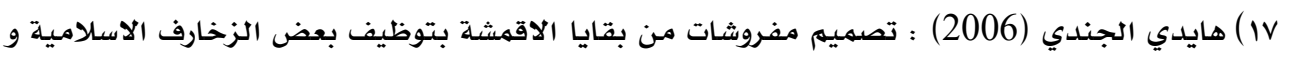

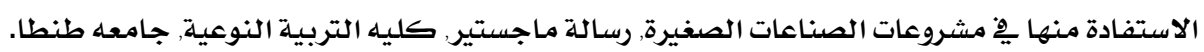

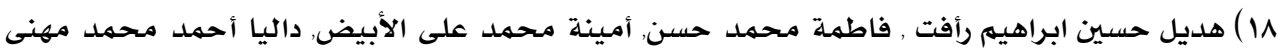

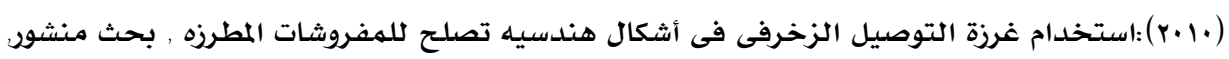

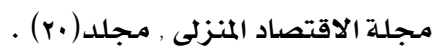


19) http://eg.sptechs.com

20) https://crafty4all.com

21) http://kenanaonline.com

22) https://www.fatakat.com

23) https://arabic.alibaba.com

24) https://arabic.alibaba.coml

25) http://edutechembroidery.com5

26) http://www.wikiwand.com

27) http://ar.gofreedownload.net/free-photos/red/red-handle-scissors139203/\#.WuDYBdRuZdg

28) https://www.ward2u.com

29) http://ghazlelbanat.com/

30) https://www.arageek.com 1

31) http://www.vb.eqla3.com

32) https://www.ward2u.com

33) https://vb.3dlat.com

34) http://forums.betel3z.com

35) https://www.kanbkam.com

36) http://www.lakii.com.

37) https://dzh.univanet.com/page/834/

38) http://simsimdiary.blogspot.com

39) https://www.hawaaworld.com/

40) http://sidamslema.forumegypt.net/t2212-topic

41) http://www.djelfa.info/vb/showthread.php?t=2016653 


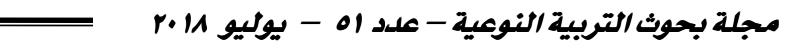

Evaluation of the Functional and Aesthetic Performance of Embroidered Beddings (towels) with Embroidery Style by Satin Stripes

\section{Abstract}

The purpose of the research is to evaluate the functional and aesthetic performance of embroidery beddings (towels) with Embroidery Style by Satin Stripes: Using the aesthetic values of the embroidery art with satin stripes to enrich and produce home beddings (towels) by using simple stitches with less time, effort and cost. Also, to know the best embroidery stitching with designed beddings stripes (towels) and to produce home embroidered beddings (towels) with high fashion stain stripes that are available in the local market as well as to recognize the importance of the performance quality and its impact on the functional and aesthetic aspects of the designed beddings (towels). Thirty-one of towels are designed and evaluation form involving three aspects (the functional, aesthetic and quality performance) is prepared. The designed beddings (towels) are evaluated in the light of evaluation form by 11 specialized juries .

The most important results were as follows :

On the functional aspect, the best designed beddings of towels were number $(14,22)$ and the least one was $(25)$. On the aesthetic aspect, we find the best one was number (22) and the least was number (19). On the quality performance, the best one was number (22), while the least was number (13). On the evaluation aspect, the best one (as a whole) was number (22) and the least was (13). 